\title{
Institutional cross-ownership and corporate strategy: the case of mergers and acquisitions
}

Article

Accepted Version

Creative Commons: Attribution-Noncommercial-No Derivative Works 4.0

Brooks, C., Chen, Z. and Zeng, Y. (2018) Institutional crossownership and corporate strategy: the case of mergers and acquisitions. Journal of Corporate Finance, 48. pp. 187-216. ISSN 0929-1199 doi:

https://doi.org/10.1016/j.jcorpfin.2017.11.003 Available at https://centaur.reading.ac.uk/73681/

It is advisable to refer to the publisher's version if you intend to cite from the work. See Guidance on citing.

To link to this article DOI: http://dx.doi.org/10.1016/j.jcorpfin.2017.11.003

Publisher: Elsevier

All outputs in CentAUR are protected by Intellectual Property Rights law, including copyright law. Copyright and IPR is retained by the creators or other copyright holders. Terms and conditions for use of this material are defined in the End User Agreement.

www.reading.ac.uk/centaur 
Central Archive at the University of Reading

Reading's research outputs online 


\title{
Institutional Cross-ownership and Corporate Strategy: The Case of Mergers and Acquisitions*
}

\author{
Chris Brooks ${ }^{\dagger 1}$, Zhong Chen $^{2}$ and Yeqin Zeng ${ }^{1}$ \\ ${ }^{1}$ ICMA Centre, Henley Business School, University of Reading, Reading RG6 6BA, United Kingdom \\ ${ }^{2}$ King's Business School, King's College London, London WC2B 4BG, United Kingdom
}

\begin{abstract}
This article provides new evidence on the important role of institutional investors in affecting corporate strategy. Institutional cross-ownership between two firms not only increases the probability of them merging, but also affects the outcomes of mergers and acquisitions (M\&As). Institutional cross-ownership reduces deal premiums, increases stock payment in M\&A transactions, and lowers the completion probabilities of deals with negative acquirer announcement returns. Furthermore, deals with high institutional crossownership have lower transaction costs and disclose more transparent financial statement information. The effect of cross-ownership on the total deal synergies and post-deal longterm performance is positive, which can be attributed to independent and non-transient cross-owners. Our findings are robust after mitigating the cross-ownership asymmetry concern. Overall, our results suggest that the growth of institutional cross-holdings in U.S. stock markets may greatly change corporate strategies and decision-making processes.
\end{abstract}

Keywords: Institutional Investors; Cross-ownership; Mergers and Acquisitions (M\&As) JEL classifications: G23; G30; G34;

*We would like to thank Jeffry Netter (the Editor) ad an anonymous referee of this journal, Alex Edmans, Anup Srivastava, Chris Florakis, Eliezer Fich, Guanming He, Ian Tonks, Kevin Mullally, Marc Lipson, Naciye Sekerci, and Raghu Rau for their helpful comments. We would also like to thank seminar participants at the ICMA Centre (Henley Business School), University of Liverpool Management School, Wuhan University, Jinan University, Queen's University Belfast, Birmingham University, University of Bath, University of Kent, the BAFA 2016 annual conference, EFMA 2016 annual conference, FMA 2016 annual conference, SFA 2016 annual conference, and 2016 Paris Financial Management conference for their insightful and constructive comments.

${ }^{\dagger}$ Corresponding author at: ICMA Centre, Henley Business School, University of Reading, Reading, Berkshire RG6 6BA, United Kingdom. Tel. +44(0)118 378 8239. E-mail addresses: c.brooks@icmacentre.ac.uk (C. Brooks), zhong.1.chen@kcl.ac.uk (Z. Chen), y.zeng@icmacentre.ac.uk (Y. Zeng). 


\section{Introduction}

Previous studies suggest that institutional ownership keeps growing in U.S. stock markets and has an important role in both corporate strategy and equity pricing (e.g., Allen, 2001; Gompers and Metrick, 2001; Bethel et al., 2009; Rydqvist et al., 2014; McCahery et al., 2016). Institutional investors manage portfolios that are not only much greater in financial terms than those of most retail investors, but also contain much larger numbers of stocks. ${ }^{1}$ Compared to retail investors, there is a much higher probability that institutional investors will become owners of the stocks on both sides of a proposed merger deal - i.e., they hold shares in both the acquirer and the target. In the context of mergers and acquisitions (M\&As), this is termed an "institutional cross-holding."

In this paper, we investigate the externality of institutional cross-holdings for corporate strategies through an important corporate event: M\&As. Unlike non cross-owners, who only hold the stock on one side of a merger deal, cross-holders tend to make decisions from a broader perspective that nets off any potential losses from one side (usually the acquirer) with gains made on the other (usually the target) and will consider how the newly formed joint entity would sit within their portfolios compared with the two existing separate stocks. Therefore, cross-holders may have different information sets, different incentive structures and may make different choices than those that would have arisen for single stock holders of either acquirers or targets. Furthermore, institutional cross-owners may have an important governance role in the M\&A process, reducing information asymmetry and mitigating the bargaining and transaction costs that would normally arise between entirely independent parties. ${ }^{2}$ Understanding whether and how institutional cross-ownership affects M\&A decision making and deal outcomes are, by

\footnotetext{
${ }^{1}$ Over the 1980-2010 period, on average, a representative institution held 219 stocks in a portfolio with the market value of $\$ 2.5$ billion (Zeng, 2016).

${ }^{2} \mathrm{~A}$ typical example where institutional cross-owners have influenced an M\&A deal is Tesla's acquisition of SolarCity in 2016. According to Thomson Reuters (June 21, 2016) and the Wall Street Journal (July 19, 2016), $45 \%$ of Tesla's shareholders hold SolarCity's stock and three of Tesla's top five institutional investors are also among SolarCity's top five institutional investors. Top cross-owners like Fidelity even expressed a willingness for a "potential future partnership" between the two firms a long time before the deal announcement. Tesla's CEO, Elon Musk, also admitted that "institutional shareholders had some idea of the plan (acquisition)", and "this idea has been bandied about with some of our largest shareholders, institutional shareholders. Yeah, there have been discussions". The deal was finally approved by over $85 \%$ of unaffiliated shareholders.
} 
themselves, of particular importance.

Empirically observing the effects of institutional cross-holdings on intercorporate activities is extremely difficult because the bulk of these activities takes place behind closed doors. Moreover, it is difficult to separate the impact of institutional investor activism from the myriad of other factors that could have caused the same outcomes. ${ }^{3}$ M\&A events present a natural arena within which to test the effect of cross-holdings on corporate strategy since they represent identifiable events and cross-holdings are observable in both acquirers and targets. Cross-owners may be actively involved in the M\&A decision-making process because these deals have substantial impacts on the wealth of both acquirers and targets.

This paper provides direct answers to two main research questions. We first examine whether institutional cross-ownership increases the likelihood of two given firms merging in the first place. One possibility is that institutional cross-ownership establishes a connection between two firms and facilitate their merger, similar to the mechanism of board member social connections (Ishii and Xuan, 2014) or common auditors (Cai et al., 2016) between the acquirer and target documented in recent M\&A studies. The other possibility is that crossownership between two firms may deter them from merging. Cross-owners may benefit from the diversification of their investment among different firms. From a cross-owner's point of view, there is a trade off between the benefits of cross-holding and the costs of under-diversification (He and Huang, 2017). In addition, Azar et al. (2017) document that common ownership in the U.S. airline industry increases market concentration and deters competition. If common owners can affect the product prices of their holding firms and already benefit from less product market competition, they may have less incentive to approve a merger.

We next investigate how institutional cross-ownership affects actual M\&A deal outcomes and performance. One hypothesis is that institutional cross-holdings are mainly due to the rise of institutional investors (Gompers et al., 2003) and the growth of index or quasi-index tracking

\footnotetext{
${ }^{3}$ For example, activist shareholders often take the credit for improvements in a firm's environmental performance following a disaster, but it appears likely that such a firm, when faced with negative publicity, severe reputation damage and a variety of unhappy stakeholders, would have taken positive steps to fix the problem anyway (e.g., Haigh and Hazelton, 2004).
} 
funds (Harford et al., 2011) in U.S. stock markets. Additionally, a single institutional crossowner may not act differently from other institutional non cross-owners because its holdings of acquirer and target stocks may be asymmetric (Harford et al., 2011). Under this view, institutional cross-ownership should have no effect at all on M\&A deal outcomes.

An alternative hypothesis is that extensive institutional cross-ownership between acquirers and targets leads to inferior M\&A deal outcomes, such as lower acquirer announcement returns; there are several reasons for this. First, the conflict of interest between institutional crossowners and other institutional owners who hold either acquirer or target stocks alone may have negative externalities for corporate strategies. Second, acquiring firm managers aiming to build an empire would choose targets with high institutional cross-ownership only because they will encounter less resistance in deal negotiations and not because these targets are the most appropriate when viewed from other perspectives. Third, institutional cross-ownership may create negative managerial behavioral traits, such as familiarity biases or predisposition to the availability heuristic, ${ }^{4}$ under which acquirers only bid for familiar firms and forgo other potential targets.

The second alternative hypothesis is that there is a positive association between institutional cross-ownership and M\&A deal outcomes. This viewpoint also receives intuitive support from three perspectives. First, institutional cross-owners may act as an information bridge between acquirers and targets and foster an enhanced information flow. Information asymmetry between acquirer and target shareholders is one of the primary causes of M\&A failure (Dong et al., 2006). An example of institutional cross-owners helping to reduce information asymmetry is that they play a "bridge-building" role for firms competing in a product market. Because institutional cross-owners have economies of scale in information production, cross-held firms within the same product market have more collaborative and innovative activities (He and Huang, 2017).

Second, institutional cross-owners can monitor the managers of both acquirers and targets.

\footnotetext{
${ }^{4}$ Tversky and Kahneman (1973), for example, provide evidence on the availability heuristic based on several experiments.
} 
More broadly, the effectiveness of the equity market is built on the premise that shareholders possess an important role in corporate governance, ensuring that firms maximize the interests of shareholders. Yet the literature highlights that different shareholder groups may have divergent incentives and may fulfill this monitoring role to varying degrees of effectiveness. Institutional investors who engage in monitoring activities will have the ability to influence management directly and will also have access to superior and more timely information (e.g., Martin, 1996; Carleton et al., 1998; Chen et al., 2007). Furthermore, institutional cross-owners may benefit from internalizing the corporate governance externality among peer firms held in their portfolios (He et al., 2017), that is, an improvement in a firm's governance leads to an improvement in governance in the firms within the same industry. Compared to other institutional investors, cross-owners have lower information collection costs and better incentives to monitor M\&A deals because they have their feet in both the acquirer and target companies.

Third, the existence of institutional cross-owners impacts upon M\&A deal negotiations. There is already evidence to suggest that close connections between the boards of the acquirer and the target (where, for example, there is a board member in common), helps acquirers to reduce their takeover premiums due to reduced information asymmetry and reduced competition from less informed potential outside bidders (e.g., Cai and Sevilir, 2012; Guo et al., 2015). Acquiring firm shareholders who also cross-hold shares in the targets may help facilitate deal negotiations, obtain better terms for acquirers and better enable the integration of the constituent firms. In addition, it is likely that institutional cross-owners know more about deal quality than other investors in the market. Therefore, institutional cross-owners may prefer certain deal characteristics to others - for example, regarding the method of payment.

Our paper is related to two studies on cross-ownership in M\&As. Matvos and Ostrovsky (2008) show that institutional investors as a whole do not lose money at the M\&A deal announcement because many of them also hold target stocks, which potentially solves the puzzle that institutional investors of acquirers approve deals with negative acquirer announcement returns. The losses due to the decrease in acquirer stock prices will be compensated by the gains due to the rise of target stock prices. Therefore, there is potentially a conflict of interest 
between an acquirer's institutional cross-owners and other investors. Matvos and Ostrovsky (2008) find evidence in the shareholder voting data that mutual fund cross-owners tend to vote for M\&As with negative acquirer announcement returns, while mutual fund non cross-owners tend to vote against these deals. Contrary to Matvos and Ostrovsky (2008), Harford et al. (2011) argue that the aggregate wealth change across all cross-owners is not equivalent to individual cross-owners' wealth changes at the deal announcement. If the shareholdings of acquirers and targets are asymmetric at the individual cross-owner level, one institutional cross-owner may only effectively focus on their position in either the acquirer or the target. These two papers examine the change of institutional cross-owners' wealth at deal announcement but hold different views of whether the existence of institutional cross-ownership can explain the negative acquirer announcement returns.

Different from Matvos and Ostrovsky (2008) and Harford et al. (2011), we do not try to resolve the overall negative acquirer announcement return puzzle in M\&As. Instead, we argue that even though individual cross-owners may lose money at the deal announcement due to the ownership asymmetry, they still have strong preferences towards their cross-held firms when exerting their influence on M\&As. Cross-owners can lose less in such deals through their stake in the target and benefit from improved deal quality. To mitigate the cross-ownership asymmetry concern indicated by Harford et al. (2011), we define alternative cross-ownership measures by requiring cross-owners to hold at least $1 \%$ shares of both acquirers and targets and by counting the number of cross-owners that are the top 5/10/20 largest owners of both acquirers and targets. We investigate whether and how these institutional cross-ownership measures affect the probability of M\&A deal occurrence, deal characteristics, and combined wealth changes in the merged firms. In this way, our paper emphasizes the importance of the institutional crossowner's externality in M\&A transactions, which may not be captured in the cross-owners' wealth change at the deal announcement. We find that institutional cross-owners affect M\&A transactions along several dimensions. Our finding that institutional cross-owners facilitate M\&A deals is consistent with Matvos and Ostrovsky's (2008) mutual fund voting studies. Our paper is not contrary to Harford et al. (2011). Even though cross-ownership asymmetry 
indicates that institutional cross-owners have different interests in deal acquirers and targets, it does not exclude the possibility that cross-owners may affect deal outcomes. Institutional crossowners may help to improve deal quality because they can alleviate information asymmetries (He and Huang, 2017) and monitor both sides in M\&As (He et al., 2017; Kang et al., 2017).

In our sample of 2,604 mergers between U.S. public firms from 1984 to 2014, we observe that institutional cross-ownership is pervasive between acquirers and targets. On average, $18 \%$ of acquirer stocks are held by target institutional owners and $21 \%$ of target stocks are held by acquirer institutional owners. Moreover, some institutional cross-owners hold a large amount of both acquirer and target stocks. For cross-owners who have more than $1 \%$ ownership in both acquirers and targets, they hold $8 \%$ of acquirer shares and $8 \%$ of target shares on average. Among the top 10 acquirer institutional owners and top 10 target institutional owners, the average number of institutional cross-owners is two. To examine the role of institutional cross-owners in M\&As, we first show that the presence of institutional cross-ownership between two firms increases the probability of a merger pair formation. Institutional crossownership measures are higher in our actual M\&A sample than those in matched firms selected by bootstrapping with replacement from the sample acquirer or target's industry. In addition, candidate firms sharing large institutional cross-ownership with sample targets (acquirers) are more likely to become actual acquirers (targets).

We next examine whether the existence of institutional cross-ownership affects M\&A deal outcomes. Using the takeover premium estimated by the transaction value in excess of target market value or by the target three-day abnormal announcement return (CAR), we find that acquirers with higher institutional cross-ownership pay lower premiums for targets. One more institutional top 10 cross-owner reduces the transaction value relative to target market value by $8.9 \%$ and the target CAR by $1.2 \%$. We also find that acquirers with high institutional cross-ownership tend to use more stock as the method of payment. One more institutional top 10 cross-owner increases stock payment by $4.3 \%$. We show that the existence of institutional cross-ownership reduces the completion probability of deals with negative acquirer CAR, but has no effect on the completion probability of deals with positive acquirer CAR. One more 
institutional top 10 cross-owner reduces the completion probability of negative CAR deals by $1.2 \%$. To support the information bridge role of institutional cross-ownership in M\&As, we study the relationship between institutional cross-ownership and deal transaction costs. For an average deal, we show that one more institutional top 10 cross-owner is associated with a $\$ 0.9$ million reduction in acquirer financial advisor fees and a $\$ 1.0$ million reduction in target financial advisor fees. Finally, we document that a merged firm is less likely to restate its earnings if institutional cross-ownership between the acquirer and the target is higher, suggesting that institutional cross-owners may reduce deal uncertainty by deterring the chance of misreporting earnings before M\&As. One more institutional top 10 cross-owner reduces the probability of earnings restatements by $1.3 \%$. These results favor the view that institutional cross-owners play an important role in corporate M\&As.

Given the evidence that institutional cross-ownership fosters M\&As and affects the transactions along several dimensions, we further investigate the relationship between institutional cross-ownership and M\&A total deal performance. Our results indicate that M\&A deal synergies, measured by acquirer and target market value-weighted average announcement returns, tend to be higher in the presence of many institutional cross-owners. One more top 10 institutional cross-owner is associated with a $2.0 \%$ increase in deal synergies. This supports the view that the positive impact of cross-ownership outweighs any negative conflict of interest effects that might be present. To better understand the synergy result, we separate institutional cross-owners by type and investigate whether this value creation is associated with a particular group of institutional investors. We find no significant relationship between deal synergies and grey cross-owner numbers and between deal synergies and transient cross-owner numbers. However, the effects of independent cross-owner numbers and non-transient cross-owner numbers on deal synergies are significantly positive. ${ }^{5}$ To mitigate the endogeneity concern due to reverse causality and potential omitted variables, we use indicator variables representing the switches of acquirers and targets between the Russell 1000 index and the Russell 2000 index before the deal

\footnotetext{
${ }^{5}$ Grey institutions have business ties with their holding firms, while independent institutions do not (Almazan et al., 2005; Chen et al., 2007). We divide institutions into transient and non-transient ones according to Bushee's (1998) classification.
} 
announcement as instrumental variables. The positive relationship between deal synergies and the number of cross-owners remains robust with the instrumental variable approach. Finally, we explore whether the positive impact of cross-ownership extends to the post-deal long-term performance. We show that various measures of post-deal long-term performance are positively related to the numbers of independent and non-transient cross-owners.

The remainder of the paper is structured as follows. Section 2 discusses the relevant literature and the possible role of institutional cross-owners in M\&As. Section 3 discusses the data collection and provides descriptive statistics. Section 4 presents empirical evidence on how institutional cross-ownership is related to M\&A deal probability and outcomes. Section 5 provides robustness test results and Section 6 concludes.

\section{Related literature}

Our paper contributes to three strands of the literature. First, to the recently developing literature on the role of cross-owners in corporate activities. Jung (2013) finds that crossownership provides a communication channel among firms and helps facilitate the diffusion of disclosure practices. Antón et al. (2016) show theoretically and empirically that the common ownership within an industry may affect top executives' compensation. Chemmanur et al. (2016) find that common blockholders with more than 5\% holdings foster strategic alliances between firms and further improve corporate innovation. Edmans et al. (2017) develop a theoretical model and show that investors who own multiple firms actually have more information on their holdings and may choose to hold firms with higher quality. Therefore, common ownership actually improves corporate governance through both voice and exit channels. Azar et al. (2017) find that common ownership affects U.S. airline companies' flight ticket pricing strategies. He and Huang (2017) document that firms with greater cross-holdings are associated with higher market share growth and more innovation productivity. He et al. (2017) show that institutional cross-owners play a monitoring role and improve firm governance through the externality of the governance improvement among peer firms in their portfolios. The cross- 
owners' monitoring effectiveness is further supported by Kang et al. (2017) who attribute the effectiveness of cross-owner monitoring to their information advantage and governance experience.

In addition to the modest literature on institutional cross-holdings, there is also some research investigating the effect of direct inter-company share holdings, where one company holds shares in another. This practice is common in Germany and Japan, but less so elsewhere including the U.S. (Bøhren and Norli, 1997). One such situation where corporate cross-holdings occur in the U.S. is in the context of "toehold" bidders, where firms that intend to make an acquisition already hold a small percentage of the equity in the target firm. Toeholding is increasingly rare in the U.S., however, but has been the subject of considerable research (e.g., Mikkelson and Ruback, 1985; Shleifer and Vishny, 1986; Betton and Eckbo, 2000; Goldman and Qian, 2005; Povel and Sertsios, 2014). ${ }^{6}$ Our empirical evidence demonstrates that the externality of general institutional cross-ownership also exists in M\&A deals.

Second, our results add to studies investigating how the links between acquirers and targets impact M\&A deal outcomes. For example, acquirer and target industry relatedness (Levy and Sarnat, 1970); acquirers and targets funded by common venture capital (e.g., Gompers and Xuan, 2008; Masulis and Nahata, 2011); supplier and customer relationships between merging firms (Ahern and Harford, 2014); toeholds (e.g., Betton and Eckbo, 2000; Goldman and Qian, 2005); acquirer-target social ties through board directors and senior executives (e.g., Cai and Sevilir, 2012; Ishii and Xuan, 2014); and common auditors (e.g., Cai et al., 2016; Dhaliwal et al., 2016). Our paper documents that institutional cross-ownership, as a new link between acquirers and targets, has a significant impact on M\&As. A key difference between institutional cross-ownership and the links documented in the previous literature is that at the outset we are agnostic about the likely sign of the impact of cross-owners on M\&A deal performance. On the one hand, acquirers with significant cross-holdings in the targets are likely to hold superior information on the true value of the latter and institutional cross-ownership may mitigate principal-agent problems arising from information asymmetries. Also, institutional cross-owners

\footnotetext{
${ }^{6}$ According to (Betton et al., 2009), only $13 \%$ of bidders for U.S. firms in the 1973-2002 period had toeholds.
} 
may monitor the managers of both acquirers and targets and offer more negotiation power to acquirers. On the other hand, institutional cross-ownership may lead to more severe conflicts of interest because the changes in institutional cross-owners' wealth are a combination of the changes in acquirer and target firm value at the deal announcement.

Third, our paper is related to studies examining the role of institutional investors in corporate strategies and investment decisions. Previous studies find that some, but not all, types of institutional investors exert influence on corporate strategies such as anti-takeover amendments, R\&D investment decisions, CEO compensation, corporate spin-offs, and earnings management (e.g., Brickley et al., 1988; Agrawal and Mandelker, 1990; Bushee, 1998; Hartzell and Starks, 2003; Abarbanell et al., 2003; Kim et al., 2016). As in M\&As, Gaspar et al. (2005) find that institutional investors with high-turnover portfolios exert little influence on managers with regard to acquisition decisions. Chen et al. (2007) find that although the total institutional holdings do not have a positive effect on post-merger performance, concentrated holdings by independent long-term institutions do. Fich et al. (2015) show that institutional investors whose holding value in targets are among the top $10 \%$ of stocks in their portfolios exert a monitoring role in M\&As and improve deal terms for targets. These studies suggest that the extent of the presence of a certain subset of institutional investors may affect corporate strategies, rather than all institutional holdings having a homogeneous effect. Our paper studies whether the variation of another subset of institutions - institutional cross-owners - affects M\&A deal performance or not.

\section{$3 \quad$ Sample selection and descriptive statistics}

In this section we discuss our sample selection process and sample characteristics.

\subsection{M\&A sample selection}

To conduct our analyses, we first select a sample of M\&As from the Thomson Reuters Securities Data Company (SDC) Platinum Mergers and Acquisitions database with the following 
criteria. We start with all U.S. domestic M\&As announced between 1984 and 2014. Our sample begins in 1984 because the information in the SDC database is less reliable before this date (Chen et al., 2007). We require both acquirers and targets to be U.S. publicly traded companies so that we can calculate their institutional cross-ownership. Deal status is either completed or withdrawn. We exclude transactions labelled as a minority stake purchase, acquisitions of remaining interest, privatizations, repurchases, exchange offers, self-tenders, recapitalizations or spin-offs. The percentage of target shares held by the acquirer must be less than $50 \%$ before the transaction and at least $90 \%$ if the transaction is completed. Deals with missing transaction value, with deal value less than $\$ 1$ million and with relative size between acquirers and targets below $5 \%^{7}$ are excluded from our sample. Finally, we limit our sample to deals in which the acquirer has accounting data available from Compustat and stock data available from the Center for Research in Security Prices (CRSP).

To examine the influence of institutional cross-ownership on deal performance, we link our M\&A sample with the Thomson Financial CDA/Spectrum Institutional (13F) database. Our final sample includes 2,604 deals in which both acquirers and targets have institutional owners. ${ }^{8}$ Panel A of Table 1 provides the distribution of M\&A deals by year. The maximum number of deals per annum is 200 and the minimum number of deals per annum is 29. Consistent with the merger wave literature, we observe that the number of deals peaks around 1997 and 2007 over our sample period. Panel B presents the distribution of M\&A deals by Fama-French 10-industry classification based on acquirers' SIC codes. Firms in the consumer nondurables, consumer durables and manufacturing industries are most active in acquisition activities. These two panels show that our sample is fairly representative and well diversified across different industries. Both year and industry fixed effects are controlled for in our multivariate regression

\footnotetext{
${ }^{7}$ We choose the relative size between acquirers and targets to be $5 \%$ because institutional cross-ownership plays a more important role in $\mathrm{M} \& \mathrm{~A}$ when acquirers and targets have a similar size. However, our results are qualitatively the same if we choose $1 \%, 10 \%$ or $20 \%$ as the relative size. The minimum deal value and relative size are not the sample selection criterion in Harford et al. (2011). We add these two sample selection criterion to exclude deals in which the targets are mechanically too small to matter for institutional cross-owners.

${ }^{8}$ The acquirers and targets of 123 deals in our sample do not share the same institutional owners. The institutional cross-ownership measures for these deals are all, therefore, defined as zero. Our empirical results are robust to the exclusion of these deals.
} 
analyses because M\&A deal numbers vary notably across time and industry.

\subsection{Sample descriptive statistics}

Table 2 presents the descriptive statistics of M\&A deals in our sample. All variables are defined in Appendix A. Panel A of Table 2 illustrates the summary statistics for the deal performance-related variables. The acquirer CARs are on average negative around deal announcements. The mean (median) deal premium is $79 \%(47 \%)$ in our sample and the mean (median) deal synergy gain is $4 \%(2 \%)$. $82 \%$ of the deals in our sample are successfully completed after the announcement. On average, the long-run abnormal returns of the completed deals are around zero.

Panel B of Table 2 summarizes the institutional cross-ownership proxy variables. On average, $18 \%$ of the acquirer's stock is owned by institutional investors who also own the equity of targets (Ac_CrossIO), while $21 \%$ of the target's stock is owned by institutional investors who also own the equity of acquirers (Ta_CrossIO). After we apply a $1 \%$ ownership threshold restriction on cross-ownership in acquirers and targets, Ac_CrossIO_1\% and Ta_CrossIO_1\% have a mean of $8 \%$ and $8 \%$, respectively. The market value weighted average of the acquirer and target's institutional cross-ownership (MVweighted_CrossIO) has a mean of 19\%. The mean number of institutional investors who are within the top five/ten/twenty largest institutional owners of both acquirers and targets (Top5/10/20Count) is 0.8/2.1/4.6. These summary statistics suggest that institutional cross-ownership is pervasive among deal acquirers and targets in our sample. Harford et al. (2011) argue that because individual institutional cross-owners' holdings are asymmetric between acquirers and targets, the average loss on acquirer announcement returns cannot be simply explained by total institutional cross-holdings. By focusing on the institutional investors who are influential on both sides of M\&A deals, our cross-ownership proxy variables help us to mitigate the concern that cross-ownership is asymmetric and cross-owners do not have an impact on both sides of M\&A deals (Harford et al., 2011). ${ }^{9}$

\footnotetext{
${ }^{9}$ On average, institutional cross-owners who are within both acquirer and target's 5/10/20 largest institutional investors hold a total of $3.6 \% / 6.6 \% / 10.3 \%$ of acquirer stocks and 3.7\%/6.7\%/10.3\% target stocks.
} 
Figure 1 presents the time series of institutional cross-ownership among the acquirers and targets in our sample. The heights of the blue (green) bars represent the average numbers of acquirer (target) institutional owners for all deals in each year. The heights of the red bars represent the average number of institutional cross-owners for all deals in each year. Due to the rise of institutional ownership in U.S. stock markets over our sample period, we observe a clear increasing pattern for all three colored bars. Because acquirers are usually larger than the corresponding targets in M\&As, the average number of acquirer institutional owners is higher than the average number of target institutional owners. The purple (red) colored line represents the average ratio of institutional cross-owners to the number of acquirer (target) institutional owners in each year. Both lines show that institutional cross-owners account for a significant

portion of acquirer and target institutional owners. For targets in particular, cross-owners account for more than $40 \%$ of target institutional owners for all the sample period.

Panel C of Table 2 presents the descriptive statistics for deal and firm characteristics. Our M\&A sample is similar to those used in previous studies of M\&As between U.S. public firms.

\section{Main results}

\subsection{Institutional cross-ownership and M\&A likelihood}

In this section, we implement both univariate and multivariate analyses to study the effect of institutional cross-ownership on the likelihood of two firms participating in M\&As.

\subsubsection{Institutional cross-ownership and M\&A likelihood: Univariate tests}

If the presence of institutional cross-ownership could have an impact on the probability of a merger occurring in the first place, then the acquisition may be more or less likely to occur between two firms that have a high institutional cross-ownership. Panel B of Table 2 presents the average institutional cross-ownership between the acquirers and the targets in our sample. We next compare these statistics to those estimated in our bootstrapped deal samples.

Following Ishii and Xuan (2014), we pair the acquirer of each sample deal with a random 
firm drawn from the sample target's industry in the year of the deal announcement. We bootstrap 500 targets with replacement for each deal and report the average institutional crossownership calculated for these simulated parings in Panel A of Table 3. Across six different institutional cross-ownership measures, we show that the observed level of institutional crossownership between our sample acquirers and sample targets is higher than one would expect from pairing actual acquirers with randomly drawn targets. Panel B of Table 3 reports the average institutional cross-ownership between random acquirers and sample targets which we construct by pairing each sample target with a random firm drawn (with replacement) from the sample acquirer's industry in the year of the deal announcement and repeat the procedure 500 times. The observed level of institutional cross-ownership in our sample is higher than one would expect from randomly pairing potential acquirers with actual targets. Panel $\mathrm{C}$ of Table 3 reports the average institutional cross-ownership between random acquirers and random targets which we construct by pairing one randomly drawn (with replacement) firm from the actual acquirer's industry with one randomly drawn firm (with replacement) from the actual target's industry. The observed level of institutional cross-ownership in our sample is higher than one would expect from randomly pairing potential acquirers with potential targets. To be consistent with our sample selection criterion, we restrict the relative size between any pair of acquirers and targets to be above $5 \%$ in our bootstrapped sample. Fama-French 10-industry classification is used our univariate analysis. ${ }^{10}$

In summary, the univariate test results based on the bootstrapped samples suggest that two firms are more likely to merge together in the presence of higher institutional crossownership. However, the probability of a firm being an acquirer or a target may also depend on firm characteristics that are not controlled for in our univariate tests. It is necessary to check the robustness of our results in multivariate regression analyses.

\footnotetext{
${ }^{10}$ Our results are robust to all other Fama-French industry classifications.
} 


\subsubsection{Probability of firms being acquirers/targets: Multivariate tests}

Following Bodnaruk et al. (2009), Bena and Li (2014), and Cai et al. (2016), we estimate the selection models of firms becoming acquirers or targets in M\&As. We start by investigating the relationship between institutional cross-ownership and the probability of a firm being an acquirer. For each sample acquirer, we define the set of firms in the same Fama-French 10industry category of similar size (within a $20 \%$ band of market capitalization) and B/M (within a $20 \%$ band of $\mathrm{B} / \mathrm{M}$ ratio). Then we use cross-sectional data as of the fiscal year-end before the deal announcement and run a conditional logit regression in which the dependent variable is equal to one if a firm is a sample acquirer and zero otherwise. The explanatory variables are institutional cross-ownership measures and a set of acquirer firm characteristics. For each deal, there is one observation for the sample acquirer and multiple observations for the matched firms. We control for deal fixed effects in all regressions. Table 4 indicates that institutional cross-ownership between all potential acquirers and sample targets is positively related to the probability of a firm becoming an acquirer. All coefficients of institutional cross-ownership measures are positive and strongly statistically significant at the $1 \%$ level.

Table 5 presents coefficient estimates from the conditional logit regression to predict target firms. To find firms similar to deal targets, we use the same matching criteria as in Table 4. We show that there is a positive relationship between institutional cross-ownership and the probability of a firm becoming a target, controlling for a set of target firm characteristics. All coefficients of institutional cross-ownership proxies are statistically significant at the $1 \%$ level. ${ }^{11}$

Overall, the results provide answers to our first research question that institutional crossownership increases the likelihood of two firms merging in the first place compared to other potential firms with similar characteristics. In the rest of this paper, we will study our second research question as to whether institutional cross-ownership has any effect on M\&A deal outcomes and performance.

\footnotetext{
${ }^{11}$ Our results in Tables 4 and 5 are robust if we exclude matched firms that do not have any institutional cross-ownership with either deal acquirers or targets.
} 


\subsection{Institutional cross-ownership and M\&A deal outcomes}

In this section, we examine whether the existence of institutional cross-ownership affects several important M\&A deal outcomes/characteristics.

\subsubsection{Institutional cross-ownership and takeover premiums}

The deal takeover premium represents how much an acquirer pays a target in excess of its market value. We measure the deal takeover premium as the ratio between transaction value and target market value four weeks before the deal announcement, subtracting one. Using this takeover premium proxy as the dependent variable and our institutional cross-ownership proxies as key independent variables, Columns (1)-(6) of Table 6 presents the multivariate ordinary least squares (OLS) regression results on the relationship between institutional cross-ownership and takeover premiums after controlling for acquirer and deal characteristics, as well as year and industry fixed effects. We adjust the regression standard errors for heteroscedasticity following White (1980).

The primary explanatory variables of interest are the institutional cross-ownership proxy variables: Ac_CrossIO, Ac_CrossIO_1\%, Mvweighted_CrossIO and Top5/10/20Count. We find that the takeover premium is negatively and significantly related to the institutional cross-ownership proxies. Increasing acquirer institutional cross-ownership (Ac_CrossIO) by one standard deviation reduces the takeover premium by $26.4 \%$. The marginal effect of one more institutional top 10 cross-owner on the takeover premium is $-8.9 \%$. Thus the relationship between institutional cross-ownership and takeover premiums is economically significant. This finding suggests that acquirers actually benefit from institutional cross-ownership and do not overpay targets.

The existence of institutional cross-owners between acquirers and targets may improve information flow and the efficiency of communication between them. Institutional cross-ownership may also increase each firm's knowledge and understanding of the other's operations and corporate culture. The information advantage of acquirers with more institutional cross-ownership may help them to get better deal prices because they may have a bargaining advantage during 
the negotiations due to their private information about the target firm relative to outside bidders without such a connection. Furthermore, institutional cross-owners may facilitate deals with lower premium that could have been otherwise rejected by non cross-owners of targets. Finally, higher institutional cross-ownership can reduce the probability of bidder competition and target resistance. The negative relationship between institutional cross-ownership and takeover premium is similar to Betton and Eckbo's (2000) finding that toeholds are associated with lower takeover premiums. Our result is also consistent with Harford et al. (2011) who find that acquirers do not bid more aggressively in the deals with high cross-holdings.

To check the robustness of the takeover premium results, we follow Ishii and Xuan (2014) and use target abnormal returns around the acquisition announcement as an alternative proxy for takeover premiums. Compared to the takeover premium calculated by transaction value, target CARs are adjusted for market returns and the market expectation of deal completion probability. Columns (7)-(12) of Table 6 presents the OLS regression results. Using target three-day CARs as the dependent variable, we find negative and statistically significant coefficients on all the institutional cross-ownership proxy variables. If acquirer institutional cross-ownership (Ac_CrossIO) increases by one standard deviation, target CARs will be reduced by $3.7 \%$. The marginal effect of one more institutional top 10 cross-owner on target CARs is $-1.2 \%$.

\subsubsection{Institutional cross-ownership and M\&A method of payment}

Usually, the method of payment in M\&A deals is acquirer stock, cash, or a combination of the two. Exotic payment structures or option-like payment methods may also be included in M\&A deals, but they are not considered in this study. In Table 7, we test the relationship between institutional cross-ownership and the percentage of stock payment involved in the total value of the transaction, controlling for deal and firm characteristics, as well as year

and industry fixed effects. We employ Tobit regressions since the dependent variable - the percentage of stock payment - is left-censored at zero.

The positive and significant coefficients on institutional cross-ownership proxy variables 
show that greater institutional cross-ownership is on average associated with a higher fraction of stock in deal payment. ${ }^{12}$ Increasing acquirer institutional cross-ownership (Ac_CrossIO) by one standard deviation raises stock payment by $9.9 \%$. An increase of one institutional top 10 cross-owner will raise stock payment by $4.3 \%$ on average.

The results in Table 7 suggest that with more institutional cross-ownership, targets are more likely to share the risk of merged companies, which is consistent with the explanation that the existence of institutional cross-ownership reduces information asymmetry in merger deals. From the perspective of target shareholders, the payment of acquirer stocks is more risky when deal information asymmetry is high. When a target's shareholders know that the M\&A deal is of good quality, they are willing to accept the stock of the new company and to ride on the future growth opportunities. From the acquirer's point of view, its institutional owners may be reluctant to use stock to finance acquisitions because it will dilute their control of the acquirer. This concern is mitigated if some institutional owners of acquirers are also the owners of targets, especially when they hold a large percentage of target shares. Martin (1996) finds that the likelihood of stock financing decreases with an acquirer's higher institutional blockholdings. Our results indicate that because institutional cross-owners and non cross-owners have different objective functions in M\&As, they may affect corporate decisions differently.

\subsubsection{Institutional cross-ownership and deal completion probability}

Next, we investigate whether deals with more institutional cross-owners have higher completion rates. On the one hand, institutional cross-owners may help facilitate deal negotiations and have a positive effect on bid success. On the other hand, they may play a monitoring role in deal negotiations, leading to a higher likelihood that deals of bad quality will be withdrawn. To test these two possibilities, we separate our sample into one group of deals with positive acquirer CARs and the other group with negative acquirer CARs. In columns (1)-(6) of Table 8, we run probit regressions of the M\&A deal completion on the institutional cross-ownership

\footnotetext{
${ }^{12}$ Similarly, we investigate the relationship between institutional cross-ownership and the percentage of cash payment involved in the total value of the transaction. Because stock and cash are substitutes as M\&A methods of payment, we find that cash is used less in deals with more institutional cross-ownership.
} 
proxy variables in the sub-sample of deals with negative CARs, controlling for deal characteristics, firm characteristics, industry fixed effects and year fixed effects. All coefficients on the institutional cross-ownership proxy variables are negative and statistically significant, except for Top5Count. Increasing acquirer institutional cross-ownership (Ac_CrossIO) by one standard deviation reduces the completion probability of negative CAR deals by $3.5 \%$. The marginal effect of one more institutional top 10 cross-owner is a 1.2\% drop in the completion probability of negative CAR deals.

In columns (7)-(12) of Table 8, we run probit regressions of M\&A deal completion on the institutional cross-ownership proxy variables for the sub-sample of deals with positive CARs, controlling for deal characteristics, firm characteristics, industry fixed effects and year fixed effects. The coefficients on the institutional cross-ownership proxy variables are positive but not statistically significant, indicating that there is no effect of institutional cross-ownership on deal completion for the positive CAR sub-sample. Overall, our findings in Table 8 support the view that institutional cross-owners have a monitoring role in M\&A deal negotiations, so that deals with negative CARs will be more likely to be withdrawn. ${ }^{13}$

\subsubsection{Institutional cross-ownership and transaction costs}

Investment banks are generally hired by acquiring firms to identify potential deals with high synergy, facilitate M\&A transactions (McLaughlin, 1990, 1992) and provide professional advice such as fairness opinions (Kisgen et al., 2009). Golubov et al. (2012) also find that for deals with both public acquirers and targets, investment banks with a better reputation may deliver higher acquirer announcement returns. If firms connected by institutional cross-owners have greater information and better knowledge about deal long-term profitability, their need for hiring investment banks to provide professional advice might be lower. Therefore, we predict that M\&A advisory fees are lower for deals with high institutional cross-ownership.

\footnotetext{
${ }^{13}$ In an untabulated test, we find that there is no significant relationship between institutional cross-ownership and takeover success for all deals in our sample. This result is different from those of Jennings and Mazzeo (1993) and Betton and Eckbo (2000), who find that toeholds are associated with a higher completion probability of M\&As. This difference further supports the monitoring role of institutional cross-owners, because compared to institutional cross-ownership, toeholds are less likely to be related to corporate governance.
} 
Table 9 presents the results of OLS regressions for advisory fees. The M\&A financial advisory fees paid by acquirers and targets are collected from SDC. In columns (1)-(6) of Table 9, the dependent variable is the ratio of advisory fees paid by the acquirers to deal value. We find that the existence of institutional cross-owners is associated with significantly lower advisory fees paid by the acquirers. A one standard deviation increase in Ac_CrossIO is associated with $0.16 \%$ decrease in the percentage advisory fees paid by the acquirers. Given the average deal value of $\$ 1,541$ million in our sample, this translates to a $\$ 2.5$ million reduction in fees paid by acquirers. The marginal effect of one more top 10 institutional cross-owner is a $0.055 \%$ decrease in the percentage advisory fees paid by the acquirers, equivalent to a $\$ 0.9$ million reduction. In columns (7)-(12) of Table 9, the dependent variable is the ratio of advisory fees paid by the targets to deal value. Similarly, we find that targets pay lower advisory fees in the presence of institutional cross-ownership. One more top 10 institutional cross-owner may reduce the percentage advisory fees paid by the targets by $0.062 \%$, translating to a $\$ 0.97$ million reduction. ${ }^{14}$ Our results are consistent with Cai and Sevilir (2012) who find that firms with current board connections pay lower M\&A financial advisory fees.

\subsubsection{Institutional cross-ownership and earnings misreporting}

Before the M\&A announcement, both acquirers (Louis, 2004; Gong et al., 2008) and targets (Anilowski et al., 2009) have an incentive to actively manage their earnings. But financial statement misreporting only benefits one side of the deal and creates greater uncertainty in M\&As. A deal with institutional cross-ownership may have less information asymmetry because cross-owners have their feet on both sides of the deal. In addition, institutional crossowners may have a greater incentive to monitor both firms and reduce misreporting activities ex ante, leading to more transparent financial information and more accurate bidding prices. Following Bens et al. (2012) and Cai et al. (2016), we use the restatements of financial reports by the newly merged firm as a proxy for misreporting and investigate whether the probability

\footnotetext{
${ }^{14}$ In untabulated tests, we also find a negative relationship between institutional cross-ownership and total deal advisory fees paid by both acquirers and targets. Only 1,703 deals in our sample have total advisory fee data from SDC. The sample characteristics do not change significantly with the availability of total investment banking fees.
} 
of a merging firm restating its earnings is negatively related to the institutional cross-ownership between the acquirer and the target. The earnings restatement data are collected from Audit Analytics. We eliminate all clerical application errors that are mainly due to unintentional reporting mistakes (Bens et al., 2012). Similarly to Cai et al. (2016), we define the earnings misreporting dummy to be equal to one if the beginning date of the misstatement period is within a two-year window before the deal completion date and zero otherwise. ${ }^{15}$

Table 10 reports the coefficient estimates from the probit regressions of the earnings misreporting dummy on the institutional cross-ownership measures. Because Audit Analytics has only covered restatement data since 1996, the deal numbers drop to 1,497 with the sample period of 1996-2014. We control for acquirer firm characteristics, target firm characteristics and deal characteristics in all regressions. All the coefficients of institutional cross-ownership measures are negative and statistically significant. The change in the probability of misreporting decreases by $3.1 \%$ for one standard deviation increase in the market value weighted institutional cross-ownership (Mvweighted_CrossIO). The marginal effect of one more institutional top 10 cross-owner is a $1.3 \%$ drop in the probability of earnings restatements. The results in Table 10 suggest that the existence of institutional cross-ownership establishes an information bridge between acquirers and targets, leading to reduced information asymmetry and deal uncertainty.

\subsection{Institutional cross-ownership and M\&A deal performance}

Our results so far establish a positive relationship between institutional cross-ownership and M\&A deal probabilities. We also show that institutional cross-ownership affects deal outcomes along several dimensions. To better understand the effect of cross-ownership on a deal's joint quality, we now examine the relationship between institutional cross-ownership and M\&A deal synergies, as well as post-merger long-term performance. It is worth noting that we do not just focus on the value effect of institutional cross-owners on only one side of the deal

\footnotetext{
${ }^{15}$ We follow Cai et al. (2016) and choose a two-year time window. More than $95 \%$ of the completed deal acquirers in our sample complete the deal within 365 days from the deal announcement. Therefore, the twoyear window covers both the fiscal year preceding the deal announcement and the fiscal year between deal announcement and completion.
} 
because institutional cross-owners hold both acquirers and targets' stocks.

\subsubsection{Institutional cross-ownership and deal synergies}

First, we proceed with the analysis of combined announcement returns as a proxy for the total value creation. The dependent variable in the multivariate OLS analysis is synergy, which is calculated as the firm market value weighted average of acquirer and target threeday announcement CARs (e.g., Bradley et al., 1988; Harford et al., 2011). The independent variable of interest is the number of institutional top 10 cross-owners. The previous literature has identified a number of deal-related and acquirer-specific factors that have a significant effect on deal announcement returns. We control for these variables in all our regressions, as well as the year and industry fixed effects. p-values are calculated based on t-statistics adjusted for heteroscedasticity. Column (1) of Panel A in Table 11 shows that synergy is positively related to the number of top 10 institutional cross-owners and the coefficient is statistically significant. The marginal effect of one more top 10 institutional cross-owner is a $2.0 \%$ increase in deal synergies.

Previous studies on the role of institutional investors in M\&As have documented that institutional investors can be classified into different types and each type may have a different effect on M\&A outcomes. Next, we follow Almazan et al. (2005) and Chen et al. (2007) and categorize the top 10 institutional cross-owners into two groups: independent (Top10CountIndependent) and grey (Top10CountGrey) institutional investors. The CDA/Spectrum classifies all institutional investors into five types: (1) banks, (2) insurance companies, (3) investment companies, (4) independent investment advisors and (5) others (e.g. pension fund, university endowment and foundation). ${ }^{16}$ We define investment companies, independent investment advisors and public pension funds as independent institutional investors. The remaining institutions are defined as grey institutional investors. Columns (2) and (3) of Panel A in Table 11 show that the coefficient of Top10CountIndependent is positive and statistically significant, while the coefficient

\footnotetext{
${ }^{16}$ We download the institutional investor type data from Professor Brian Bushee's website: http://acct. wharton.upenn.edu/faculty/bushee/IIclass.html. Professor Bushee and his research assistants assign a type code on searches for information about the new fund manager after 1998.
} 
of Top10CountGrey is not statistically significant. These results are consistent with Almazan et al. (2005) and Chen et al. (2007) that independent institutional investors are more likely to play a monitoring role in corporate governance.

We also follow Bushee (1998) and Bushee and Noe (2000) to classify institutional crossowners into: non-transient (Top10CountDedicated/Quasi-index) and transient (Top10Count Transient). ${ }^{17}$ Chen et al. (2007) document that dedicated and quasi-indexer investors play a monitoring role in M\&As. Appel et al. (2016) also find that passive mutual funds actually help to remove firms' takeover defenses and increase firms' equal voting rights. Columns (4) and (5) of Panel A in Table 11 show that the coefficient of Top10CountDedicated/Quasi - index is positive and statistically significant, while the coefficient of Top10CountTransient is not statistically significant. Our results are consistent with those documented in Chen et al. (2007) and Appel et al. (2016).

\subsubsection{Endogeneity between institutional cross-ownership and deal synergies}

One concern on the relationship between cross-ownership and deal synergies is that institutional cross-owners could buy more shares of firms that tend to get involved in M\&As and are likely to have higher deal synergies. If that is the case, the better deal synergies we observe would not be due to the influence of institutional cross-owners. To mitigate the endogeneity issue related to reverse causality and omitted variables, we employ a two-stage least squares (2SLS) approach with instrumental variables indicating the switch of firms between the Russell 1000 and the Russell 2000 indexes.

Firm switches between the two Russell indexes have been extensively used as an exogenous shock on institutional ownership in the recent literature (e.g., Boone and White, 2015; Appel et al., 2016; Bird and Karolyi, 2016; Khan et al., 2016). Chang et al. (2015) find that because both the Russell 1000 and the Russell 2000 indexes are value-weighted, Russell index tracking funds raise (reduce) their investment in firms that switch from the bottom (top) of the Russell

\footnotetext{
${ }^{17}$ These classifications are developed in Bushee (1998) and Bushee and Noe (2000). The following three dimensions of investment patterns are used in the factor clustering analyses: portfolio turnover, diversification and momentum trading.
} 
1000 (2000) to the top (bottom) of the Russell 2000 (1000). This exogenous shock on the ownership of Russell index tracking institutions may also lead to an ownership change among other non-tracking institutions. Following Fich et al. (2015), Crane et al. (2016) and Schmidt and Fahlenbrach (2017), we apply the regression discontinuity design approach and use the Russell index switch indicator variables as instrumental variables in a two-stage least squares (2SLS) estimation framework. The Russell index constituent data are downloaded from Bloomberg and are available for the period 1995-2014. In the first stage regressions, we include the following four instrumental variables: Acquirer Russell $1000_{t-1} \rightarrow 2000_{t}$ is an indicator variable equal to one if the acquirer switches from the Russell 1000 to the Russell 2000; Acquirer Russell $2000_{t-1}$ $\rightarrow 1000_{t}$ is an indicator variable equal to 1 if the acquirer switches from the Russell 2000 to the Russell 1000; Target Russell $1000_{t-1} \rightarrow 2000_{t}$ is an indicator variable equal to one if the target switches from the Russell 1000 to the Russell 2000; and Target Russell $2000_{t-1} \rightarrow 1000_{t}$ is an indicator variable equal to 1 if the target switches from the Russell 2000 to the Russell 1000. Among the 1, 867 sample deals announced during the period 1995-2014, 34 deal acquirers switch from the Russell 1000 to the Russell 2000 before the deal announcement; 72 deal acquirers switch from the Russell 2000 to the Russell 1000 before the deal announcement; 22 deal targets switch from the Russell 1000 to the Russell 2000 before the deal announcement; and 31 deal targets switch from the Russell 2000 to the Russell 1000 before the deal announcement.

The three dependent variables in the first stage regressions are the changes in Top10Count, Top10CountIndependent, and Top10CountDedicated/Quasi - index from t to t-1 before the deal announcements. Following Fich et al. (2015), for deals announced in the fourth quarter of year t, we calculate the institutional cross-owner variables at the end of the third quarter of year t. For deals announced in the first three quarters of year $t$, we calculate the institutional cross-owner variables at the end of the third quarter of year t-1. The three first stage regression results are reported in Panel B of Table 11. According to the regression results, if an acquirer switches from the Russell 1000 to the Russell 2000 before the deal announcement, there is a significant decline in institutional cross-owner numbers. ${ }^{18}$

\footnotetext{
${ }^{18}$ This result is consistent with Fich et al. (2015).
} 
In the second stage regressions, we replace the three significant top 10 cross-owner variables in Panel A of Table 11 by the fitted value for the change in the corresponding variables estimated in the first stage regressions. Panel B of Table 11 shows that the coefficients for the fitted value of the change in Top10Count, Top10CountIndependent, and Top10CountDedicated/ Quasi - index are positive and statistically significant. Overall, the results reported in Table 11 suggest that institutional cross-owners have a positive effect on M\&A deal synergies.

\subsubsection{Institutional cross-ownership and deal long-run performance}

As an alternative method to examine whether institutional cross-ownership leads to better M\&A performance, we further study the relationship between institutional cross-ownership and the merged firm's long-run performance. We focus on Top10Count, Top10CountIndependent, and Top10CountDedicated/Quasi-index in our empirical analysis because these three crossownership proxy variables have a positive and statistically significant impact on deal synergies. In columns (1)-(3) of Table 12, the dependent variable is the change in acquirer abnormal return on assets over a three-year time window after the deal announcement. In columns (4)(6) of Table 12, the dependent variable is the acquirer buy-and-hold abnormal stock return over a three-year time window after the deal announcement. The estimated coefficients of institutional cross-ownership proxy variables are all positive and statistically significant. ${ }^{19}$ The results suggest that the impact of institutional cross-owners on M\&As lasts for an extended period after the deal announcement.

\section{Discussion and robustness tests}

\subsection{Institutional cross-ownership asymmetry}

Matvos and Ostrovsky (2008) find that the total wealth change of institutional crossowners at the M\&A announcement is close to zero and mutual fund cross-owners of acquirers

\footnotetext{
${ }^{19}$ In untabulated tests, we find that Top10CountGrey and Top10Transient do not have a significant impact on the deal long-run performance.
} 
do vote for deals with negative announcement returns. However, Harford et al. (2011) argue that institutional cross-ownership at the individual level is asymmetric and that the wealth effect should not be simply added up. In this paper, we study whether the existence of crossowners affects deal probabilities and outcomes. Although the wealth change of institutional cross-owners is not the focus of our paper, it is still possible that institutional cross-owners do not have enough power to influence deals due to the cross-ownership asymmetry.

Previous cross-ownership studies usually apply an ownership threshold to address the cross-ownership asymmetry concern. Chemmanur et al. (2016) find a positive relationship between the number of common blockholders across two firms and the number of strategic alliances between them. He and Huang (2017) find that common blockholders have an impact on firms' product market performance within the same industry. We examine the institutional cross-owners who hold more than $1 \%$ of acquirer and target's stocks in our deal sample: Ac_CrossIO_1\% and Ta_CrossIO_1\%. These institutional investors have relatively symmetric and large holdings in both acquirers and targets. The maximum number of these institutional cross-owners is 20 , the minimum is zero and the average is 2.5. We find that the estimated coefficients of $A c_{-} C r o s s I O \_1 \%$ and $T a \_C r o s s I O \_1 \%$ are statistically significant in all the previously reported tables. ${ }^{20}$ He et al. (2017) adopt a peers' market value weighted cross-ownership measure and find that this measure is positively related to the likelihood that an institution votes against management in shareholder-sponsored governance proposals. Our cross-ownership proxy variable, Mvweighted_CrossIO, shares the similar intuition with He et al.'s (2017) measure. Furthermore, we use Top5/10/20Count to measure the number of cross-owners who are influential in both acquirer and target. Overall, our evidence suggests that institutional crossowners have a significant impact on M\&A transactions after controlling for the cross-ownership asymmetry.

\footnotetext{
${ }^{20}$ In untabulated tests, we further study common blockholder ownership between acquirers and targets and find qualitatively the same results.
} 


\subsection{Institutional cross-ownership vs. institutional ownership}

Institutional investors play a monitoring role in the corporate governance literature. It is possible that institutional cross-ownership is positively correlated with acquirer or target institutional ownership which could independently affect M\&A outcomes. To rule out this alternative explanation, we control for acquirer or target institutional ownership in all our regressions if appropriate. Our results suggest that the relationship between institutional crossownership and M\&A deal outcomes holds after controlling for firm institutional ownership.

Interestingly, we find some weak evidence that institutional ownership is positively and significantly related to the takeover premium in Table 6, which is the opposite to institutional cross-ownership. Similarly, we find weak evidence that institutional ownership is negatively and significantly related to the percentage of stock payment in Table 7, which is the opposite to institutional cross-ownership. Furthermore, we find that institutional ownership itself does not affect deal completion probability in Table 8. Index investing may cause an increase in both institutional ownership and cross-ownership. ${ }^{21}$ Unobserved firm characteristics may also be related to these two ownership measures. However, our results indicate that institutional cross-owners, as a subset of institutional investors, play a different role in M\&As. ${ }^{22}$ This finding mitigates the potential concern that the empirical relation between cross-ownership and deal outcomes is spurious due to the growth of index investment and unobserved firm characteristics.

\subsection{Institutional cross-ownership and other deal characteristics}

Many previous studies document a diversification discount (e.g., Lang and Stulz, 1994; Berger and Ofek, 1995; Servaes, 1996; Santos et al., 2008). Morck et al. (1990) also find that diversifying deals have a negative effect on acquirer announcement returns. We use deal diversification as a proxy for deal quality. We separate our sample into a diversifying deal sample

\footnotetext{
${ }^{21}$ Recent studies find that index funds or passive institutional investors can improve corporate governance as well (e.g., Appel et al., 2016; He et al., 2017).

${ }^{22} \mathrm{We}$ check the variance inflation factors (VIF) of institutional cross-ownership variables and institutional ownership variable in our regressions. All VIF values are less than four, which is lower than the standard collinearity tolerance level of 10 .
} 
and a non-diversifying deal sample. In untabulated univariate tests, we find that the means of institutional cross-ownership proxy variables are significantly higher for non-diversifying deals than for diversifying deals. The Wilcoxon rank-sum test confirms that the medians of the institutional cross-ownership proxy variables for non-diversifying deals are higher than those of diversifying deals. These results suggest that deals with high institutional cross-ownership are more likely to be non-diversifying.

Our findings that institutional cross-owners may facilitate deal negotiation and increase the bargaining power of acquirers would imply a positive relationship between institutional cross-ownership and the number of bids for the target. $10 \%$ of our sample deals have more than one bidder on the deal announcement. In untabulated results, we find that the presence of institutional cross-owners is positively associated with the number of deal bidders, controlling for year and industry fixed effects.

\subsection{Mechanisms through which cross-owners affect M\&As}

The most direct way that institutional cross-owners may influence corporate activities is through shareholder voting. He et al. (2017) document a positive relation between an institutional investor's cross-holdings in peer firms and the probability that the investor votes against management in shareholder-sponsored governance proposals. With regard to M\&As, Matvos and Ostrovsky (2008) find that mutual fund cross-owners are more likely to vote for a merger with negative acquirer announcement returns than mutual fund non-cross-owners. In addition, previous corporate governance studies tend to agree that some certain types of institutional investors monitor firm managers and improve firm governance (e.g. Bushee, 1998; Chen et al., 2007). In Table 11, we find that independent and dedicated cross-owners improve deal synergies while grey and transient cross-owners do not, which further lends support to the view that institutional cross-owners have an impact on M\&As through monitoring the management teams of acquirers and targets.

Another possible channel is that institutional cross-owners may mitigate deal information asymmetry because they have their feet on both acquirers and targets. He and Huang 
(2017) show that cross-owners can reduce information asymmetry among peer firms in the same industry and facilitate the collaboration between two cross-held peer firms. To verify the information asymmetry channel, we further examine the impact of targets' asymmetric information on the relation between cross-owners and deal performance. We conduct sub-sample analyses so that the coefficients may have a more nuanced interpretation. Specifically, we divide our M\&A sample into two sub-samples based on the medians of the numbers of financial analysts following, Analyst. A lower value of Analyst indicates a higher level of information asymmetry (e.g., Hong et al., 2000; Chen et al., 2015). Table 13 presents the relation between cross-ownership and deal performance in above- and below-median analyst coverage sub-samples. The deal performance measures are Synergy, $\triangle A R O A \_3 Y$, and $B H A R \_3 Y$. In Panel A-C, the explanatory variables of interest are Top10Count, Top10CountIndependent, and Top10CountDedicated/Quasi - index, respectively ${ }^{23}$. The estimated coefficients of three cross-ownership variables are positive and statistically significant in the below-median analyst coverage sub-samples, while the impact of cross-owners on deal performance is not statistically significant in the above-median analyst coverage sub-samples. Our results confirm that institutional cross-owners improve deal quality through mitigating information asymmetry.

\section{Conclusions}

Institutional investors have been demonstrated to play an important role in the financial markets and have an impact on a variety of corporate strategies. But few studies have shown how institutional investors affect firms' acquisition behavior and performance. We investigate the impact of institutional cross-ownership, where the same set of institutional investors has significant stakes in both acquirers and targets, on various aspects of deal outcomes in M\&As. Two types of institutional cross-ownership measures are studied in our empirical analysis: the percentage of shareholdings and the number of cross-owners.

We first show that institutional cross-ownership between two firms increases the likelihood

\footnotetext{
${ }^{23}$ We omit the regression results for grey and transient cross-owners as their impact is not statistically significant.
} 
of them merging. Then we show that institutional cross-ownership affects various deal characteristics and performance. We find that institutional cross-ownership reduces deal premiums, thus leading to better value for acquirers. Deals with high institutional cross-ownership tend to involve more stock as the method of payment. Cross-ownership diminishes the likelihood of bad deal completion, enhances deal synergies and is positively related to the long-run performance of the merged entities from both fundamental (operating) and stock market perspectives. We also find a negative relationship between institutional cross-ownership and deal transaction costs. Institutional cross-owners help reduce deal uncertainty by limiting earnings misreporting. Our results suggest that institutional cross-owners benefit acquirers by providing them with an information advantage about the true value of the target firm and more bargaining power in deal negotiations. Besides the positive effect of institutional cross-ownership on deal outcomes, we also document a positive relationship between cross-ownership and total deal performance, measured by the deal synergy and long-run performance. Overall we conclude that cross-ownership improves the quality of mergers, a finding which we attribute to the superior two-sided information, better monitoring role and stronger negotiating power of such investors compared with those who operate only on one side of the deal.

Our work contributes to the literature on the effect of institutional investors on corporate activities. More specifically, we demonstrate the impact of cross-firm institutional ownership in the context of mergers and acquisitions. The evidence presented in our paper is consistent with the view that different interests among shareholder groups within a firm have externalities for firm performance. We also contribute to a growing literature on the effect of firm connections in the business world. Hence the rise of institutional cross-holdings in U.S. stock markets has a significant effect on corporate strategies and decision-making processes. Following on from our study, two promising extensions exist for future research. Firstly, to examine the trading activities of institutional cross-owners before and after M\&As and in particular to investigate whether cross-owners are able to use their two-sided information to earn higher returns. Secondly, to investigate the impact of institutional cross-ownership on other corporate strategies and policies. 


\section{Highlights}

- Cross-ownership increases the likelihood of two firms merging together.

- Cross-owners have a significant impact on M\&A deal characteristics.

- Cross-ownership is positively associated with deal performance. 


\section{Appendix A}

\section{Table A1: Variable definitions}

This table provides variable definitions and the corresponding data sources. CRSP refers to the Center for Research in Security Prices, FF refers to Kenneth French's website at Dartmouth, SDC refers to the Thomson Reuters Securities Data Company, 13F refers to the Thomson Reuters 13F Database, and IBES refers to the Institutional Brokers' Estimate System.

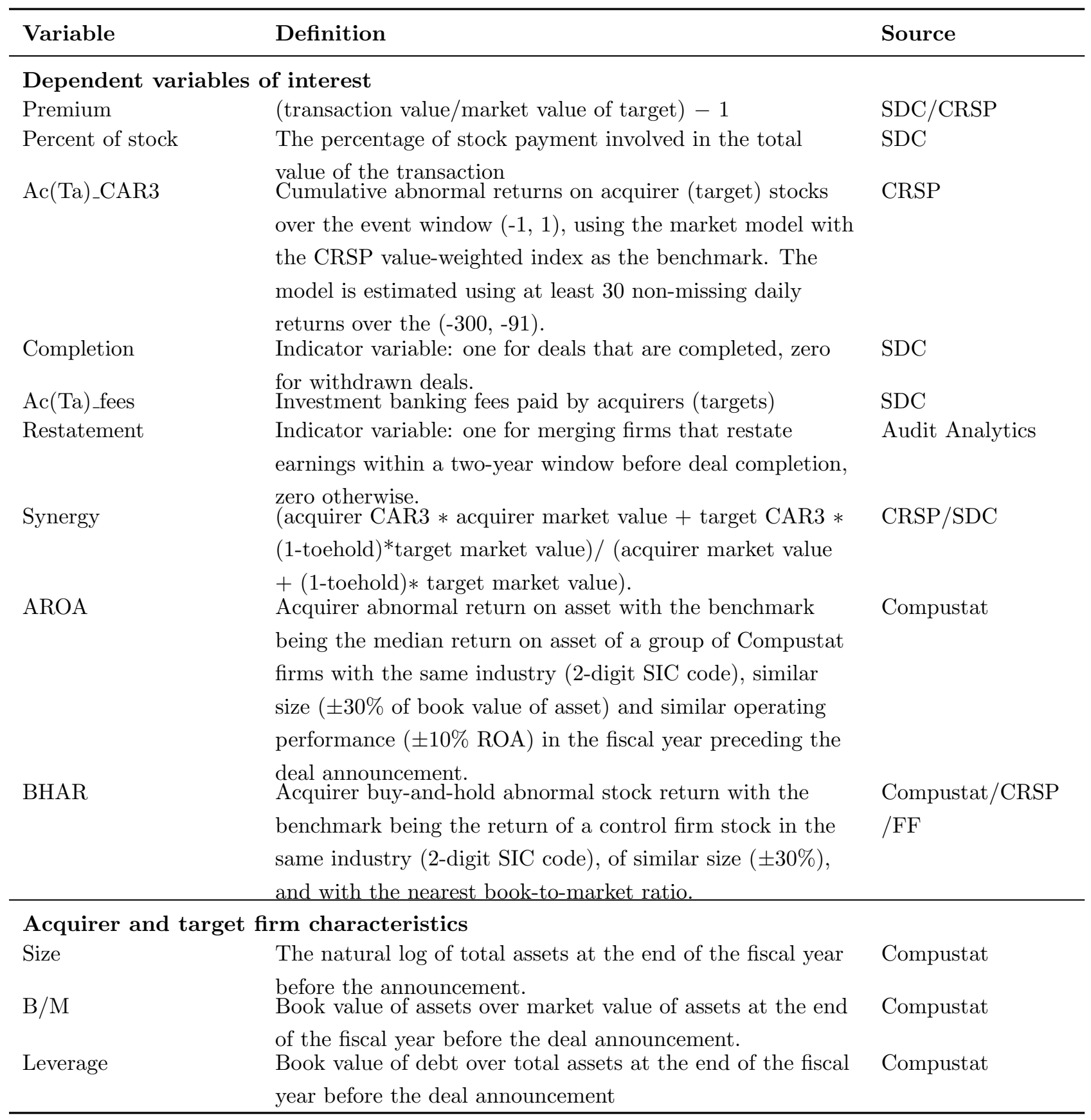


Table A1 - continued from previous page

\begin{tabular}{|c|c|c|}
\hline Variable & Definition & Source \\
\hline Cashholding & $\begin{array}{l}\text { Cash holdings, including cash and marketable securities, } \\
\text { normalized by total assets. }\end{array}$ & Compustat \\
\hline CF/Equity & $\begin{array}{l}\text { Income before extraordinary items plus depreciation minus } \\
\text { dividends on common and preferred stocks divided by firm } \\
\text { market value at the end of the fiscal year before the deal } \\
\text { announcement }\end{array}$ & Compustat \\
\hline Runup & $\begin{array}{l}\text { Market adjusted buy-and-hold stock return over the }(-205 \text {, } \\
\text {-6) window (Golubov et al., 2012). }\end{array}$ & CRSP \\
\hline Sigma & $\begin{array}{l}\text { The standard deviation of the market-adjusted daily return } \\
\text { over the }(-205,-6) \text { window (Golubov et al., 2012). }\end{array}$ & CRSP \\
\hline Collateral & $\begin{array}{l}\text { The value of the property, plant, and equipment over total } \\
\text { assets at the end of the fiscal year before the deal }\end{array}$ & Compustat \\
\hline IO & $\begin{array}{l}\text { announcement } \\
\text { Institutional ownership at the quarter end. }\end{array}$ & $13 \mathrm{~F}$ \\
\hline $\mathrm{ROA}$ & Operating cash flows over total assets. & Compustat \\
\hline Sales_Growth & Percentage change in sales from the previous year. & Compustat \\
\hline Analyst & The number of analysts following targets & IBES \\
\hline \multicolumn{3}{|l|}{ Deal characteristics } \\
\hline Pure_Cash & Indicator variable: one for deals financed fully with cash, & $\mathrm{SDC}$ \\
\hline Pure_Stock & $\begin{array}{l}\text { zero otherwise. } \\
\text { Indicator variable: one for deals financed fully with stock, }\end{array}$ & $\mathrm{SDC}$ \\
\hline Toehold & $\begin{array}{l}\text { zero otherwise. } \\
\text { Indicator variable: one if the acquirer already holds a } \\
\text { certain percentage of the target shares at the }\end{array}$ & $\mathrm{SDC}$ \\
\hline Hostile & $\begin{array}{l}\text { announcement, zero otherwise. } \\
\text { Indicator variable: one for hostile deals, zero otherwise. }\end{array}$ & $\mathrm{SDC}$ \\
\hline Tender_Offer & Indicator variable: one for tender offers, zero otherwise. & $\mathrm{SDC}$ \\
\hline Diversifying & Indicator variable: one if the target and acquirer have & $\mathrm{SDC}$ \\
\hline Competition & $\begin{array}{l}\text { different two-digit SIC Codes, zero otherwise } \\
\text { Indicator variable: one if more than one firm is bidding for } \\
\text { the target, zero otherwise }\end{array}$ & $\mathrm{SDC}$ \\
\hline Relative_Size & $\begin{array}{l}\text { The ratio of transaction value to acquirer market value at } \\
\text { the end of the fiscal year before the deal announcement. }\end{array}$ & SDC/Compustat \\
\hline \multicolumn{3}{|c|}{ Institutional cross-ownership variables } \\
\hline $\mathrm{Ac}(\mathrm{Ta})_{-} \mathrm{CrossIO}$ & $\begin{array}{l}\text { Ownership by acquirer (target) institutions that own target } \\
\text { (acquirer) shares. }\end{array}$ & $13 \mathrm{~F}$ \\
\hline Ac(Ta)_CrossIO_1\% & $\begin{array}{l}\text { Ownership by acquirer (target) institutions that own target } \\
\text { (acquirer) shares, with a } 1 \% \text { threshold restriction on } \\
\text { accuirer and target institutional ownership. }\end{array}$ & $13 \mathrm{~F}$ \\
\hline Mvweighted_CrossIO & $\begin{array}{l}\text { acquirer and target institutional ownership. } \\
\text { Ac_CrossIO } * \text { acquirer market value/(acquirer market value } \\
+ \text { target market value) }+ \text { Ta_CrossIO } * \text { target market } \\
\text { value/(acquirer market value }+ \text { target market value })\end{array}$ & $13 \mathrm{~F} /$ Compustat \\
\hline Top5/10/20Count & $\begin{array}{l}\text { Number of institutions that are within both acquirer's and } \\
\text { target's top } 5 / 10 / 20 \text { largest institutional owners. }\end{array}$ & $13 \mathrm{~F}$ \\
\hline
\end{tabular}




\section{References}

Abarbanell, J. S., Bushee, B. J., Raedy, J. S., 2003. Institutional investor preferences and price pressure: The case of corporate spin-offs. Journal of Business 76, 233-261.

Agrawal, A., Mandelker, G. N., 1990. Large shareholders and the monitoring of managers: The case of antitakeover charter amendments. Journal of Financial and Quantitative Analysis 25, $143-161$.

Ahern, K. R., Harford, J., 2014. The importance of industry links in merger waves. Journal of Finance 69, 527-576.

Allen, F., 2001. Do financial institutions matter? Journal of Finance 4, 1165-1175.

Almazan, A., Hartzell, J. C., Starks, L. T., 2005. Active institutional shareholders and costs of monitoring: Evidence from executive compensation. Financial Management 34, 5-34.

Anilowski, C., Macias, A. J., Sanchez, J. M., 2009. Target firm earnings management and the method of sale: Evidence from auctions and negotiations. Working Paper, SSRN eLibrary.

Antón, M., Ederer, F., Giné, M., Schmalz, M. C., 2016. Common ownership, competition, and top management incentives. Working Paper, Available at SSRN 2802332.

Appel, I. R., Gormley, T. A., Keim, D. B., 2016. Passive investors, not passive owners. Journal of Financial Economics 121, 111-141.

Azar, J., Schmalz, M. C., Tecu, I., 2017. Anti-competitive effects of common ownership. Journal of Finance, Forthcoming.

Barber, B. M., Lyon, J. D., 1996. Detecting abnormal operating performance: The empirical power and specification of test statistics. Journal of Financial Economics 41, 359-399.

Barber, B. M., Lyon, J. D., 1997. Detecting long-run abnormal stock returns: The empirical power and specification of test statistics. Journal of Financial Economics 43, 341-372.

Bena, J., Li, K., 2014. Corporate innovations and mergers and acquisitions. Journal of Finance 69, 1923-1960.

Bens, D. A., Goodman, T. H., Neamtiu, M., 2012. Does investment-related pressure lead to misreporting? An analysis of reporting following M\&A transactions. The Accounting Review 87, 839-865.

Berger, P. G., Ofek, E., 1995. Diversification's effect on firm value. Journal of Financial Economics 37, 39-65.

Bethel, J. E., Hu, G., Wang, Q., 2009. The market for shareholder voting rights around mergers and acquisitions: Evidence from institutional daily trading and voting. Journal of Corporate Finance 15, 129-145.

Betton, S., Eckbo, B. E., 2000. Toeholds, bid jumps, and expected payoffs in takeovers. Review of Financial Studies 13, 841-882.

Betton, S., Eckbo, B. E., Thorburn, K. S., 2009. Merger negotiations and the toehold puzzle. Journal of Financial Economics 91, 158-178.

Bird, A., Karolyi, S. A., 2016. Do institutional investors demand public disclosure? Review of Financial Studies 29, 3245-3277.

Bodnaruk, A., Massa, M., Simonov, A., 2009. Investment banks as insiders and the market for corporate control. Review of Financial Studies 22, 4989-5026. 
Bøhren, Ø., Norli, Ø., 1997. Determinants of intercorporate shareholdings. European Finance Review 1, 265-287.

Boone, A. L., White, J. T., 2015. The effect of institutional ownership on firm transparency and information production. Journal of Financial Economics 117, 508-533.

Bradley, M., Desai, A., Kim, E. H., 1988. Synergistic gains from corporate acquisitions and their division between the stockholders of target and acquiring firms. Journal of Financial Economics 21, 3-40.

Brickley, J. A., Lease, R. C., Jr., C. W. S., 1988. Ownership structure and voting on antitakeover amendments. Journal of Financial Economics 20, 267-291.

Bushee, B. J., 1998. The influence of institutional investors on myopic R\&D investment behavior. The Accounting Review 73, 305-333.

Bushee, B. J., Noe, C. F., 2000. Corporate disclosure practices, institutional investors, and stock return volatility. Journal of accounting research 38, 171-202.

Cai, Y., Kim, Y., Park, J. C., White, H. D., 2016. Common auditors in M\&A transactions. Journal of Accounting and Economics 61, 77-99.

Cai, Y., Sevilir, M., 2012. Board connections and M\&A transactions. Journal of Financial Economics 103, 327-349.

Carleton, W. T., Nelson, J. M., Weisbach, M. S., 1998. The influence of institutions on corporate governance through private negotiations: Evidence from TIAA-CREF. Journal of Finance $53,1335-1362$.

Chang, Y.-C., Hong, H., Liskovich, I., 2015. Regression discontinuity and the price effects of stock market indexing. Review of Financial Studies 28, 212-246.

Chemmanur, T. J., Shen, Y., Xie, J., 2016. Innovation beyond firm boundaries: Common blockholders, strategic alliances, and corporate innovation. Working Paper, Available at SSRN 2668000 .

Chen, T., Harford, J., Lin, C., 2015. Do analysts matter for governance? Evidence from natural experiments. Journal of Financial Economics 115, 383-410.

Chen, X., Harford, J., Li, K., 2007. Monitoring: Which institutions matter? Journal of Financial Economics 86, 279-305.

Crane, A. D., Michenaud, S., Weston, J. P., 2016. The effect of institutional ownership on payout policy: Evidence from index thresholds. Review of Financial Studies hhw012, 1-32.

Dhaliwal, D. S., Lamoreaux, P. T., Litov, L. P., Neyland, J. B., 2016. Shared auditors in mergers and acquisitions. Journal of Accounting and Economics 61, 49-76.

Dong, M., Hirshleifer, D., Richardson, S., Teoh, S. H., 2006. Does investor misvaluation drive the takeover market? Journal of Finance 61, 725-762.

Duchin, R., Schmidt, B., 2013. Riding the merger wave: Uncertainty, reduced monitoring, and bad acquisitions. Journal of Financial Economics 107, 69-88.

Edmans, A., Levit, D., Reilly, D., 2017. The effect of diversification on price informativeness and governance. Working Paper, Available at SSRN 2482935.

Fich, E. M., Harford, J., Tran, A. L., 2015. Motivated monitors: The importance of institutional investors' portfolio weights. Journal of Financial Economics 118, 21-48. 
Gaspar, J.-M., Massa, M., Matos, P., 2005. Shareholder investment horizons and the market for corporate control. Journal of Financial Economics 76, 135-165.

Goldman, E., Qian, J., 2005. Optimal toeholds in takeover contests. Journal of Financial Economics 77, 321-346.

Golubov, A., Petmezas, D., Travlos, N. G., 2012. When it pays to pay your investment banker: New evidence on the role of financial advisors in M\&As. Journal of Finance 67, 271-311.

Gompers, P., Ishii, J., Metrick, A., 2003. Corporate governance and equity prices. Quarterly Journal of Economics 118, 107-156.

Gompers, P. A., Metrick, A., 2001. Institutional investors and equity prices. Quarterly Journal of Economics 116, 229-259.

Gompers, P. A., Xuan, Y., 2008. Bridge building in venture capital-backed acquisitions. Working Paper, Harvard Business School, Boston, MA.

Gong, G., Louis, H., Sun, A. X., 2008. Earnings management, lawsuits, and stock-for-stock acquirers' market performance. Journal of Accounting and Economics 46, 62-77.

Guercio, D. D., Seery, L., Woidtke, T., 2008. Do boards pay attention when institutional investor activists "just vote no"? Journal of Financial Economics 90, 84-103.

Guo, J., Li, X., Seeger, N. C., Vagenas-Nanos, E., 2015. Social connections, reference point and M\&A performance. Working Paper, University of Durham, UK.

Haigh, M., Hazelton, J., 2004. Financial markets: a tool for social responsibility? Journal of Business Ethics 52, 59-71.

Harford, J., Jenter, D., Li, K., 2011. Institutional cross-holdings and their effect on acquisition decisions. Journal of Financial Economics 99, 27-39.

Hartzell, J. C., Starks, L. T., 2003. Institutional investors and executive compensation. Journal of Finance 58, 2351-2374.

He, J., Huang, J., 2017. Product market competition in a world of cross-ownership: Evidence from institutional blockholdings. Review of Financial Studies 30, 2674-2718.

He, J., Huang, J., Zhao, S., 2017. Internalizing governance externalities: The role of institutional cross-ownership. Working Paper, Available at SSRN 2940227.

Hong, H., Lim, T., Stein, J. C., 2000. Bad news travels slowly: Size, analyst coverage, and the profitability of momentum strategies. Journal of Finance 55, 265-295.

Huson, M. R., Malatesta, P. H., Parrino, R., 2004. Managerial succession and firm performance. Journal of Financial Economics 74, 237-275.

Ishii, J., Xuan, Y., 2014. Acquirer-target social ties and merger outcomes. Journal of Financial Economics 112, 344-363.

Jennings, R. H., Mazzeo, M. A., 1993. Competing bids, target management resistance, and the structure of takeover bids. Review of Financial Studies 6, 883-909.

Jung, M. J., 2013. Investor overlap and diffusion of disclosure practices. Review of Accounting Studies 18, 167-206.

Kang, J.-K., Luo, J., Na, H. S., 2017. Are institutional investors with multiple blockholdings effective monitors? Working Paper, Available at SSRN 2024700.

Khan, M., Srinivasan, S., Tan, L., 2016. Institutional ownership and corporate tax avoidance: New evidence. Working Paper, Available at SSRN 2779809. 
Kim, I., Miller, S., Wan, H., Wang, B., 2016. Drivers behind the monitoring effectiveness of global institutional investors: Evidence from earnings management. Journal of Corporate Finance 40, 24-46.

Kisgen, D. J., Qian, J., Song, W., 2009. Are fairness opinions fair? The case of mergers and acquisitions. Journal of Financial Economics 91, 179-207.

Lang, L. H., Stulz, R. M., 1994. Tobin's q, corporate diversifications, and firm performance. Journal of Political Economy 102, 1248-1280.

Levy, H., Sarnat, M., 1970. Diversification, portfolio analysis and the uneasy case for conglomerate mergers. Journal of Finance, 795-802.

Louis, H., 2004. Earnings management and the market performance of acquiring firms. Journal of Financial Economics 74, 121-148.

Lyon, J. D., Barber, B. M., Tsai, C.-L., 1999. Improved methods for tests of long-run abnormal stock returns. Journal of Finance 54, 165-201.

Martin, K. J., 1996. The method of payment in corporate acquisitions, investment opportunities, and management ownership. Journal of Finance, 1227-1246.

Masulis, R. W., Nahata, R., 2011. Venture capital conflicts of interest: Evidence from acquisitions of venture-backed firms. Journal of Financial and Quantitative Analysis 46, 395-430.

Matvos, G., Ostrovsky, M., 2008. Cross-ownership, returns, and voting in mergers. Journal of Financial Economics 89, 391-403.

McCahery, J. A., Sautner, Z., Starks, L. T., 2016. Behind the scenes: The corporate governance preferences of institutional investors. Journal of Finance 71, 2905-2932.

McLaughlin, R. M., 1990. Investment-banking contracts in tender offers: An empirical analysis. Journal of Financial Economics 28, 209-232.

McLaughlin, R. M., 1992. Does the form of compensation matter? Investment banker fee contracts in tender offers. Journal of Financial Economics 32, 223-260.

Mikkelson, W. H., Ruback, R. S., 1985. An empirical analysis of the interfirm equity investment process. Journal of Financial Economics 14, 523-553.

Morck, R., Shleifer, A., Vishny, R. W., 1990. Do managerial objectives drive bad acquisitions? Journal of Finance 45, 31-48.

Povel, P., Sertsios, G., 2014. Getting to know each other: The role of toeholds in acquisitions. Journal of Corporate Finance 26, 201-224.

Rydqvist, K., Spizman, J., Strebulaev, I., 2014. Government policy and ownership of equity securities. Journal of Financial Economics 111, 70-85.

Santos, M. B. D., Errunza, V. R., Miller, D. P., 2008. Does corporate international diversification destroy value? Evidence from cross-border mergers and acquisitions. Journal of Banking and Finance 32, 2716-2724.

Schmidt, C., Fahlenbrach, R., 2017. Do exogenous changes in passive institutional ownership affect corporate governance and firm value? Journal of Financial Economics In press.

Servaes, H., 1996. The value of diversification during the conglomerate merger wave. Journal of Finance 51, 1201-1225.

Shleifer, A., Vishny, R. W., 1986. Large shareholders and corporate control. Journal of Political Economy, 461-488. 
Tversky, A., Kahneman, D., 1973. Availability: A heuristic for judging frequency and probability. Cognitive psychology 5, 207-232.

White, H., 1980. A heteroskedasticity-consistent covariance matrix estimator and a direct test for heteroskedasticity. Econometrica 48, 817-838.

Zeng, Y., 2016. Institutional investors: Arbitrageurs or rational trend chasers. International Review of Financial Analysis 45, 240-262. 


\section{Table 1: Sample distribution}

Panel A. Distribution of M\&As by year. This panel presents the sample distribution of completed and withdrawn U.S. M\&A deals between 1984 and 2014 by announcement year. Both the acquirers and the targets are public firms with complete information in the CRSP and Compustat databases. We also require that both the acquirers and the targets have institutional ownership information from the Thomson Financial CDA/Spectrum Institutional (13F) database.

\begin{tabular}{ccc|ccc}
\hline Year & Deal number & Percent & Year & Deal number & Percent \\
\hline 1984 & 41 & 1.57 & 2000 & 152 & 5.84 \\
1985 & 51 & 1.96 & 2001 & 128 & 4.92 \\
1986 & 63 & 2.42 & 2002 & 56 & 2.15 \\
1987 & 55 & 2.11 & 2003 & 96 & 3.69 \\
1988 & 59 & 2.27 & 2004 & 95 & 3.65 \\
1989 & 48 & 1.84 & 2005 & 84 & 3.23 \\
1990 & 29 & 1.11 & 2006 & 88 & 3.38 \\
1991 & 38 & 1.46 & 2007 & 87 & 3.34 \\
1992 & 30 & 1.15 & 2008 & 69 & 2.65 \\
1993 & 68 & 2.61 & 2009 & 49 & 1.88 \\
1994 & 109 & 4.19 & 2010 & 59 & 2.27 \\
1995 & 134 & 5.15 & 2011 & 43 & 1.65 \\
1996 & 145 & 5.57 & 2012 & 55 & 2.11 \\
1997 & 200 & 7.68 & 2013 & 60 & 2.3 \\
1998 & 174 & 6.68 & 2014 & 59 & 2.27 \\
1999 & 180 & 6.91 & Total & 2,604 & 100 \\
\hline
\end{tabular}

Panel B. Distribution of M\&As by industry. This panel presents the sample distribution of completed and withdrawn U.S. M\&A deals between 1984 and 2014 by acquirer industry. We assign acquirers into the Fama-French 10 industries based on acquirer SIC codes. Both the acquirers and the targets are public firms with complete information in the CRSP and Compustat databases. We also require that both the acquirers and the targets have institutional ownership information the from Thomson Financial CDA/Spectrum Institutional (13F) database.

\begin{tabular}{lcc}
\hline Fama-French 10 industries & Frequency & Percent \\
\hline Consumer nondurables & 977 & 37.52 \\
Consumer durables & 549 & 21.08 \\
Manufacturing & 280 & 10.75 \\
Oil, gas and coal extraction and production & 216 & 8.29 \\
Business equipment & 167 & 6.41 \\
Telephone and television transmission & 105 & 4.03 \\
Wholesale, retail and some services & 96 & 3.69 \\
Healthcare, medical equipment and drug & 90 & 3.46 \\
Utilities & 73 & 2.80 \\
Other - mines, Constr, bldmt, trans, etc. & 51 & 1.96 \\
\hline Total & 2,604 & 100 \\
\hline
\end{tabular}




\section{Table 2: Descriptive statistics}

This table presents descriptive statistics of the variables for 2,604 M\&A deals in our sample. The sample period is between 1984 and 2014. Both the acquirer and the target are public firms with complete information in CRSP and Compustat. We also require that both the acquirer and the target have institutional ownership information from the Thomson Financial CDA/Spectrum Institutional $(13 \mathrm{~F})$ database. The number of observations, mean, standard deviation, 25th percentile, median and 75th percentile are reported from left to right in sequence for each variable. Detailed definitions of all variables can be found in Appendix A.

Panel A. Deal outcome and performance-related variables

\begin{tabular}{lcccccc}
\hline Variable & Obs. & Mean & S.D. & p25 & p50 & p75 \\
\hline Ac_CAR3 & 2,588 & -0.02 & 0.08 & -0.05 & -0.01 & 0.02 \\
Ta_CAR3 & 2,590 & 0.20 & 0.22 & 0.06 & 0.17 & 0.30 \\
Premium & 2,602 & 0.79 & 2.29 & 0.24 & 0.47 & 0.85 \\
Percent of stock & 2,604 & 53.70 & 44.20 & 0 & 60.60 & 100 \\
Completion & 2,604 & 0.82 & 0.38 & 1 & 1 & 1 \\
Ac_fees & 777 & $0.66 \%$ & $0.67 \%$ & $0.26 \%$ & $0.48 \%$ & $0.82 \%$ \\
Ta_fees & 1,636 & $0.89 \%$ & $0.80 \%$ & $0.40 \%$ & $0.77 \%$ & $1.14 \%$ \\
Restatement & 1,879 & 0.07 & 0.26 & 0 & 0 & 0 \\
Synergy & 2,554 & 0.04 & 0.81 & -0.02 & 0.02 & 0.06 \\
AROA_3Y & 1,777 & $-0.43 \%$ & $14.29 \%$ & $-2.71 \%$ & $-0.04 \%$ & $2.00 \%$ \\
BHAR_3Y & 2,148 & $-0.30 \%$ & $4.38 \%$ & $-1.87 \%$ & $-0.23 \%$ & $1.36 \%$ \\
\hline
\end{tabular}

Panel B. Institutional cross-ownership proxy variables

\begin{tabular}{lcccccc}
\hline Variable & Obs. & Mean & S.D. & p25 & p50 & p75 \\
\hline Ac_CrossIO & 2,604 & 0.18 & 0.18 & 0.04 & 0.12 & 0.30 \\
Ac_CrossIO_1\% & 2,604 & 0.08 & 0.09 & 0.01 & 0.04 & 0.12 \\
Ta_CrossIO & 2,604 & 0.21 & 0.20 & 0.05 & 0.14 & 0.33 \\
Ta_CrossIO_1\% & 2,604 & 0.08 & 0.10 & 0.01 & 0.05 & 0.13 \\
Mvweighted_CrossIO & 2,604 & 0.19 & 0.18 & 0.04 & 0.13 & 0.30 \\
Top5Count & 2,604 & 0.83 & 0.90 & 0 & 1 & 1 \\
Top10Count & 2,604 & 2.06 & 1.51 & 1 & 2 & 3 \\
Top20Count & 2,604 & 4.59 & 2.73 & 3 & 4 & 6 \\
Top10CountIndependent & 2,604 & 1.17 & 1.14 & 0 & 1 & 2 \\
Top10CountGrey & 2,604 & 0.89 & 0.99 & 0 & 1 & 1 \\
Top10CountDedicated/Quasi-index & 2,604 & 1.77 & 1.41 & 1 & 2 & 3 \\
Top10CountTransient & 2,604 & 0.24 & 0.56 & 0 & 0 & 0 \\
\hline
\end{tabular}


Panel C. Deal and firm characteristic variables

\begin{tabular}{lcccccc}
\hline Variable & Obs. & Mean & S.D. & p25 & p50 & p75 \\
\hline \multicolumn{7}{l}{ Deal characteristics } \\
Pure_Cash & 2,604 & 0.24 & 0.42 & 0 & 0 & 0 \\
Pure_Stock & 2,604 & 0.39 & 0.49 & 0 & 0 & 1 \\
Toehold & 2,604 & 0.06 & 0.24 & 0 & 0 & 0 \\
Hostile & 2,604 & 0.05 & 0.22 & 0 & 0 & 0 \\
Tender_Offer & 2,604 & 0.16 & 0.37 & 0 & 0 & 0 \\
Diversifying & 2,604 & 0.3 & 0.46 & 0 & 0 & 1 \\
Competition & 2,604 & 0.1 & 0.29 & 0 & 0 & 0 \\
Relative_Size & 2,604 & 0.62 & 1.29 & 0.14 & 0.32 & 0.69 \\
Acquirer firm characteristics & & & \\
IO & 2,604 & 0.51 & 0.27 & 0.30 & 0.51 & 0.73 \\
Size & 2,595 & 7.18 & 1.98 & 5.82 & 7.19 & 8.50 \\
B/M & 2,560 & 2.05 & 3.38 & 1.06 & 1.31 & 2.00 \\
Leverage & 2,595 & 58.92 & 26.99 & 38.35 & 58.12 & 85.79 \\
Cashholding & 2,592 & 0.15 & 0.18 & 0.03 & 0.07 & 0.20 \\
CF/Equity & 2,594 & 0.05 & 0.27 & 0.03 & 0.06 & 0.10 \\
Runup & 2,601 & 1.15 & 0.51 & 0.90 & 1.08 & 1.27 \\
Sigma & 2,601 & 0.02 & 0.02 & 0.01 & 0.02 & 0.03 \\
Collateral & 2,517 & 0.21 & 0.23 & 0.02 & 0.13 & 0.33 \\
ROA & 2,601 & 0.10 & 0.14 & 0.03 & 0.10 & 0.16 \\
Sales_Growth & 2,596 & 0.29 & 0.87 & 0.02 & 0.13 & 0.31 \\
Target firm characteristics & & & & \\
IO & 2,604 & 0.39 & 0.28 & 0.15 & 0.34 & 0.61 \\
Size & 2,601 & 5.23 & 1.77 & 3.94 & 5.08 & 6.44 \\
Leverage & 2,563 & 58.48 & 29.56 & 34.71 & 57.66 & 85.97 \\
B/M & 2,503 & 1.76 & 2.09 & 1.02 & 1.20 & 1.76 \\
Cashholding & 2,555 & 0.16 & 0.20 & 0.02 & 0.06 & 0.22 \\
ROA & 2,339 & 0.20 & 0.65 & -0.01 & 0.10 & 0.23 \\
Sales_Growth & 2,437 & 0.06 & 0.19 & 0.02 & 0.08 & 0.15 \\
Runup & 2,595 & 1.12 & 1.48 & 0.82 & 1.04 & 1.29 \\
Sigma & 2,595 & 0.03 & 0.02 & 0.02 & 0.03 & 0.04 \\
\hline
\end{tabular}


Table 3: Probability of acquisition and institutional cross-ownership: Univariate tests

This table examines whether an M\&A deal is more likely to occur between two firms that have a high institutional cross-ownership. Panel A reports the average institutional cross-ownership measures between sample acquirers and random targets, which we construct by pairing each sample acquirer with a random firm drawn from the sample target's industry in the deal announcement year. We restrict the relative size between the random target and sample acquirer to be above $5 \%$. Following this procedure, we bootstrap 500 random targets. Panel B reports the average institutional cross-ownership measures between random acquirers and sample targets, which we construct by pairing each sample target with a random firm drawn from the sample acquirer's industry in the deal announcement year. We restrict the relative size between the sample target and random acquirer to be above $5 \%$. Following this procedure, we bootstrap 500 random acquirers. Panel $\mathrm{C}$ reports the average institutional crossownership measures between random acquirers and random targets, which we construct by drawing one random firm from the sample acquirer's industry and one random firm from the sample target's industry in the deal announcement year for each acquisition in our sample. We restrict the relative size between the random target and random acquirer to be above $5 \%$. We repeat the procedure 500 times. All institutional cross-ownership measures are calculated at the quarter end before the deal announcement. $* * *, * *$, and $*$ denote statistical significance at the $1 \%, 5 \%$, and $10 \%$ levels, respectively.

\begin{tabular}{lccccl}
\hline \multicolumn{5}{c}{$\begin{array}{c}\text { Panel A. Sample acquirers and random targets } \\
\text { Real sample }\end{array}$} \\
& $\begin{array}{l}\text { Mean } \\
\text { Meanulated sample }\end{array}$ & S.D. & Mean & S.D. & Real-simulated \\
\cline { 2 - 6 } & 0.18 & 0.18 & 0.17 & 0.14 & $0.01^{* *}$ \\
Ac_CrossIO & 0.04 & 0.09 & 0.02 & 0.07 & $0.02^{* * *}$ \\
Ac_CrossIO_1\% & 0.19 & 0.18 & 0.17 & 0.13 & $0.02^{* * *}$ \\
Mvweighted_CrossIO & 0.83 & 0.90 & 0.58 & 0.41 & $0.25^{* * *}$ \\
Top5Count & 2.07 & 1.51 & 1.58 & 0.78 & $0.49^{* * *}$ \\
Top10Count & 4.59 & 2.73 & 3.78 & 1.54 & $0.81^{* * *}$ \\
Top20Count & & & & & \\
\hline
\end{tabular}

Panel B. Random acquirers and sample targets

Ta_CrossIO

Ta_CrossIO_1\%

Mvweighted_CrossIO

Top5Count

Top10Count

Top20Count

\begin{tabular}{ccccl}
\multicolumn{2}{l}{ Real sample } & \multicolumn{2}{l}{ Simulated sample } & Difference \\
Mean & S.D. & Mean & S.D. & Real-simulated \\
\hline 0.21 & 0.21 & 0.11 & 0.11 & $0.10^{* * *}$ \\
0.08 & 0.10 & 0.05 & 0.07 & $0.03^{* * *}$ \\
0.19 & 0.18 & 0.11 & 0.10 & $0.08^{* * *}$ \\
0.83 & 0.90 & 0.51 & 0.35 & $0.32^{* * *}$ \\
2.07 & 1.51 & 1.36 & 0.68 & $0.71^{* * *}$ \\
4.59 & 2.73 & 3.03 & 1.42 & $1.56^{* * *}$
\end{tabular}

Panel C. Random acquirers and random targets

\begin{tabular}{ccccl}
\multicolumn{2}{l}{$\begin{array}{l}\text { Real sample } \\
\text { Mean }\end{array}$} & S.D. & Simulated sample & Difference \\
Mean & S.D. & Real-simulated \\
\hline 0.18 & 0.18 & 0.09 & 0.06 & $0.09^{* * *}$ \\
0.04 & 0.09 & 0.01 & 0.03 & $0.03^{* * *}$ \\
0.21 & 0.20 & 0.09 & 0.06 & $0.12^{* * *}$ \\
0.08 & 0.10 & 0.04 & 0.08 & $0.04^{* * *}$ \\
0.19 & 0.18 & 0.09 & 0.06 & $0.10^{* * *}$ \\
0.83 & 0.90 & 0.46 & 0.19 & $0.37^{* * *}$ \\
2.07 & 1.51 & 1.20 & 0.41 & $0.87^{* * *}$ \\
4.59 & 2.73 & 2.64 & 0.90 & $1.95^{* * *}$ \\
\hline
\end{tabular}




\section{Table 4: Probability of firms being acquirers and institutional cross-ownership}

This table reports the coefficient estimates from conditional logit models. The dependent variable is equal to one for the sample acquirer and zero for the matched acquirers in the control group. The matched acquirers are firms in the sample acquirer's industry (FamaFrench 10 industries), of similar size (within a $20 \%$ band of market capitalization) and of similar $\mathrm{B} / \mathrm{M}$ ratio (within a $20 \%$ band of $\mathrm{B} / \mathrm{M}$ ). The relative size between the sample target and matched acquirers is above 5\%. Detailed definitions of acquirer control variables can be found in Appendix A. Deal fixed effects are controlled for in all regressions. Robust standard errors are clustered at the deal level. p-values are reported in parentheses. Significance at the $0.01,0.05$, and 0.10 levels is indicated by $* * *, * *$, and $*$, respectively.

\begin{tabular}{|c|c|c|c|c|c|c|}
\hline & 1 & 2 & 3 & 4 & 5 & 6 \\
\hline Ac_CrossIO & $\begin{array}{c}3.565^{* * *} \\
(0.000)\end{array}$ & & & & & \\
\hline Ac_CrossiO_1\% & & $\begin{array}{c}8.912^{* * *} \\
(0.000)\end{array}$ & & & & \\
\hline Mvweighted_CrossIO & & & $\begin{array}{c}6.867^{* * *} \\
(0.000)\end{array}$ & & & \\
\hline Top5Count & & & & $\begin{array}{c}0.583^{* * *} \\
(0.000)\end{array}$ & & \\
\hline Top10Count & & & & & $\begin{array}{c}0.403^{* * *} \\
(0.000)\end{array}$ & \\
\hline Top20Count & & & & & & $\begin{array}{c}0.283^{* * *} \\
(0.000)\end{array}$ \\
\hline $\mathrm{IO}$ & $\begin{array}{c}0.683^{* * *} \\
(0.000)\end{array}$ & $\begin{array}{c}1.663^{* * *} \\
(0.000)\end{array}$ & $\begin{array}{c}1.111^{* * *} \\
(0.000)\end{array}$ & $\begin{array}{c}0.334^{* * *} \\
(0.002)\end{array}$ & $\begin{array}{c}0.305^{* * *} \\
(0.007)\end{array}$ & $\begin{array}{c}0.229^{* *} \\
(0.047)\end{array}$ \\
\hline Size & $\begin{array}{c}1.925^{* * *} \\
(0.000)\end{array}$ & $\begin{array}{c}1.825^{* * *} \\
(0.000)\end{array}$ & $\begin{array}{c}1.995^{* * *} \\
(0.000)\end{array}$ & $\begin{array}{c}1.940^{* * *} \\
(0.000)\end{array}$ & $\begin{array}{c}1.982^{* * *} \\
(0.000)\end{array}$ & $\begin{array}{c}1.967^{* * *} \\
(0.000)\end{array}$ \\
\hline $\mathrm{B} / \mathrm{M}$ & $\begin{array}{c}1.008^{* * *} \\
(0.000)\end{array}$ & $\begin{array}{c}0.930^{* * *} \\
(0.000)\end{array}$ & $\begin{array}{c}1.022^{* * *} \\
(0.000)\end{array}$ & $\begin{array}{c}1.023^{* * *} \\
(0.000)\end{array}$ & $\begin{array}{c}1.042^{* * *} \\
(0.000)\end{array}$ & $\begin{array}{c}1.053^{* * *} \\
(0.000)\end{array}$ \\
\hline Leverage & $\begin{array}{c}0.005^{* * *} \\
(0.001)\end{array}$ & $\begin{array}{c}0.007^{* * *} \\
(0.000)\end{array}$ & $\begin{array}{c}0.005^{* * *} \\
(0.000)\end{array}$ & $\begin{array}{c}0.005^{* * *} \\
(0.001)\end{array}$ & $\begin{array}{c}0.004^{* * *} \\
(0.002)\end{array}$ & $\begin{array}{c}0.004^{* * *} \\
(0.003)\end{array}$ \\
\hline $\mathrm{ROA}$ & $\begin{array}{c}-0.682^{* * *} \\
(0.009)\end{array}$ & $\begin{array}{c}-0.767^{* * *} \\
(0.005)\end{array}$ & $\begin{array}{c}-0.631^{* *} \\
(0.016)\end{array}$ & $\begin{array}{c}-0.656^{* *} \\
(0.015)\end{array}$ & $\begin{array}{c}-0.601^{* *} \\
(0.027)\end{array}$ & $\begin{array}{c}-0.538^{* *} \\
(0.046)\end{array}$ \\
\hline Cashholding & $\begin{array}{l}-0.119 \\
(0.541)\end{array}$ & $\begin{array}{c}0.013 \\
(0.945)\end{array}$ & $\begin{array}{l}-0.086 \\
(0.657)\end{array}$ & $\begin{array}{l}-0.047 \\
(0.808)\end{array}$ & $\begin{array}{l}-0.034 \\
(0.863)\end{array}$ & $\begin{array}{l}-0.046 \\
(0.814)\end{array}$ \\
\hline Sales_Growth & $\begin{array}{c}0.000 \\
(0.931)\end{array}$ & $\begin{array}{c}-0.008^{*} \\
(0.079)\end{array}$ & $\begin{array}{c}0.001 \\
(0.785)\end{array}$ & $\begin{array}{l}-0.004 \\
(0.345)\end{array}$ & $\begin{array}{l}-0.002 \\
(0.548)\end{array}$ & $\begin{array}{c}-0.001 \\
(0.733)\end{array}$ \\
\hline Runup & $\begin{array}{c}0.284^{* * *} \\
(0.000)\end{array}$ & $\begin{array}{c}0.299^{* * *} \\
(0.000)\end{array}$ & $\begin{array}{c}0.266^{* * *} \\
(0.000)\end{array}$ & $\begin{array}{c}0.281^{* * *} \\
(0.000)\end{array}$ & $\begin{array}{c}0.286^{* * *} \\
(0.000)\end{array}$ & $\begin{array}{c}0.295^{* * * *} \\
(0.000)\end{array}$ \\
\hline Sigma & $\begin{array}{c}-25.615^{* * *} \\
(0.000)\end{array}$ & $\begin{array}{c}-26.664^{* * *} \\
(0.000)\end{array}$ & $\begin{array}{c}-24.916^{* * *} \\
(0.000)\end{array}$ & $\begin{array}{c}-25.671^{* * *} \\
(0.000)\end{array}$ & $\begin{array}{c}-25.351^{* * * *} \\
(0.000)\end{array}$ & $\begin{array}{c}-25.013^{* * *} \\
(0.000)\end{array}$ \\
\hline Deal fixed effects & Yes & Yes & Yes & Yes & Yes & Yes \\
\hline Observations & 36,944 & 36,944 & 36,944 & 36,944 & 36,944 & 36,944 \\
\hline Actual acquirer No. & 2,177 & 2,177 & 2,177 & 2,177 & 2,177 & 2,177 \\
\hline Control acquirer No. & 34,767 & 34,767 & 34,767 & 34,767 & 34,767 & 34,767 \\
\hline Pseudo R-squared & 0.045 & 0.080 & 0.067 & 0.058 & 0.065 & 0.074 \\
\hline
\end{tabular}




\section{Table 5: Probability of firms being targets and institutional cross-ownership}

This table reports the coefficient estimates from conditional logit models. The dependent variable is equal to one for the sample target and zero for the matched targets in the control group. The matched targets are the firms in the sample target's industry (Fama-French 10 industries), of similar size (within a $20 \%$ band of market capitalization) and of similar B/M ratio (within a $20 \%$ band of $\mathrm{B} / \mathrm{M}$ ). The relative size between the matched targets and sample acquirers is above 5\%. Detailed definitions of target control variables can be found in Appendix A. Deal fixed effects are controlled for in all regressions. Robust standard errors are clustered at the deal level. p-values are reported in parentheses. Significance at the 0.01, 0.05, and 0.10 levels is indicated by $* * *, * *$, and $*$, respectively.

\begin{tabular}{|c|c|c|c|c|c|c|}
\hline & 1 & 2 & 3 & 4 & 5 & 6 \\
\hline Ta_CrossIO & $\begin{array}{c}3.926^{* * *} \\
(0.000)\end{array}$ & & & & & \\
\hline Ta_CrossIO_1\% & & $\begin{array}{c}10.063^{* * *} \\
(0.000)\end{array}$ & & & & \\
\hline Mvweighted_CrossIO & & & $\begin{array}{c}7.387^{* * *} \\
(0.000)\end{array}$ & & & \\
\hline Top5Count & & & & $\begin{array}{c}0.523^{* * *} \\
(0.000)\end{array}$ & & \\
\hline Top10Count & & & & & $\begin{array}{c}0.345^{* * *} \\
(0.000)\end{array}$ & \\
\hline Top20Count & & & & & & $\begin{array}{c}0.219^{* * *} \\
(0.000)\end{array}$ \\
\hline IO & $\begin{array}{c}1.346^{* * *} \\
(0.000)\end{array}$ & $\begin{array}{c}2.845^{* * *} \\
(0.000)\end{array}$ & $\begin{array}{c}1.155^{* * *} \\
(0.000)\end{array}$ & $\begin{array}{c}0.429 * * * \\
(0.000)\end{array}$ & $\begin{array}{c}0.315^{* * *} \\
(0.006)\end{array}$ & $\begin{array}{c}0.087 \\
(0.455)\end{array}$ \\
\hline Size & $\begin{array}{c}1.652^{* * *} \\
(0.000)\end{array}$ & $\begin{array}{c}1.598^{* * *} \\
(0.000)\end{array}$ & $\begin{array}{c}1.463^{* * *} \\
(0.000)\end{array}$ & $\begin{array}{c}1.567^{* * *} \\
(0.000)\end{array}$ & $\begin{array}{c}1.554^{* * *} \\
(0.000)\end{array}$ & $\begin{array}{c}1.508^{* * *} \\
(0.000)\end{array}$ \\
\hline $\mathrm{B} / \mathrm{M}$ & $\begin{array}{c}0.623^{* * *} \\
(0.000)\end{array}$ & $\begin{array}{c}0.664^{* * *} \\
(0.000)\end{array}$ & $\begin{array}{c}0.517^{* * *} \\
(0.000)\end{array}$ & $\begin{array}{c}0.581^{* * *} \\
(0.000)\end{array}$ & $\begin{array}{c}0.595^{* * *} \\
(0.000)\end{array}$ & $\begin{array}{c}0.561^{* * * *} \\
(0.000)\end{array}$ \\
\hline Leverage & $\begin{array}{c}0.013^{* * *} \\
(0.000)\end{array}$ & $\begin{array}{c}0.014^{* * * *} \\
(0.000)\end{array}$ & $\begin{array}{c}0.016^{* * *} \\
(0.000)\end{array}$ & $\begin{array}{c}0.014^{* * *} \\
(0.000)\end{array}$ & $\begin{array}{c}0.014^{* * *} \\
(0.000)\end{array}$ & $\begin{array}{c}0.015^{* * *} \\
(0.000)\end{array}$ \\
\hline ROA & $\begin{array}{l}-0.308 \\
(0.139)\end{array}$ & $\begin{array}{l}-0.180 \\
(0.401)\end{array}$ & $\begin{array}{c}-0.258 \\
(0.217)\end{array}$ & $\begin{array}{c}-0.267 \\
(0.201)\end{array}$ & $\begin{array}{c}-0.170 \\
(0.422)\end{array}$ & $\begin{array}{l}-0.099 \\
(0.632)\end{array}$ \\
\hline Cashholding & $\begin{array}{c}0.051 \\
(0.752)\end{array}$ & $\begin{array}{c}0.043 \\
(0.793)\end{array}$ & $\begin{array}{c}0.006 \\
(0.973)\end{array}$ & $\begin{array}{c}0.046 \\
(0.782)\end{array}$ & $\begin{array}{c}0.032 \\
(0.844)\end{array}$ & $\begin{array}{c}0.066 \\
(0.685)\end{array}$ \\
\hline Sales_Growth & $\begin{array}{c}-0.019^{* * *} \\
(0.009)\end{array}$ & $\begin{array}{l}-0.013^{*} \\
(0.088)\end{array}$ & $\begin{array}{c}-0.018^{* * *} \\
(0.006)\end{array}$ & $\begin{array}{c}-0.017^{* * *} \\
(0.009)\end{array}$ & $\begin{array}{c}-0.019^{* * *} \\
(0.003)\end{array}$ & $\begin{array}{c}-0.017^{* *} \\
(0.011)\end{array}$ \\
\hline Runup & $\begin{array}{c}0.051^{* *} \\
(0.035)\end{array}$ & $\begin{array}{c}0.040 \\
(0.102)\end{array}$ & $\begin{array}{c}0.047^{* *} \\
(0.049)\end{array}$ & $\begin{array}{c}0.053^{* *} \\
(0.025)\end{array}$ & $\begin{array}{c}0.055^{* *} \\
(0.047)\end{array}$ & $\begin{array}{c}0.057^{*} \\
(0.070)\end{array}$ \\
\hline Sigma & $\begin{array}{c}-10.680^{* * * *} \\
(0.000)\end{array}$ & $\begin{array}{c}-11.425^{* * *} \\
(0.000)\end{array}$ & $\begin{array}{c}-10.988^{* * *} \\
(0.000)\end{array}$ & $\begin{array}{c}-9.921^{* * *} \\
(0.000)\end{array}$ & $\begin{array}{c}-9.734^{* * *} \\
(0.000)\end{array}$ & $\begin{array}{c}-9.759^{* * *} \\
(0.000)\end{array}$ \\
\hline Deal fixed effects & Yes & Yes & Yes & Yes & Yes & Yes \\
\hline Observations & 44,388 & 44,388 & 44,388 & 44,388 & 44,388 & 44,388 \\
\hline Actual target No. & 2,145 & 2,145 & 2,145 & 2,145 & 2,145 & 2,145 \\
\hline Control target No. & 42,243 & 42,243 & 42,243 & 42,243 & 42,243 & 42,243 \\
\hline Pseudo R-squared & 0.040 & 0.105 & 0.056 & 0.045 & 0.049 & 0.051 \\
\hline
\end{tabular}




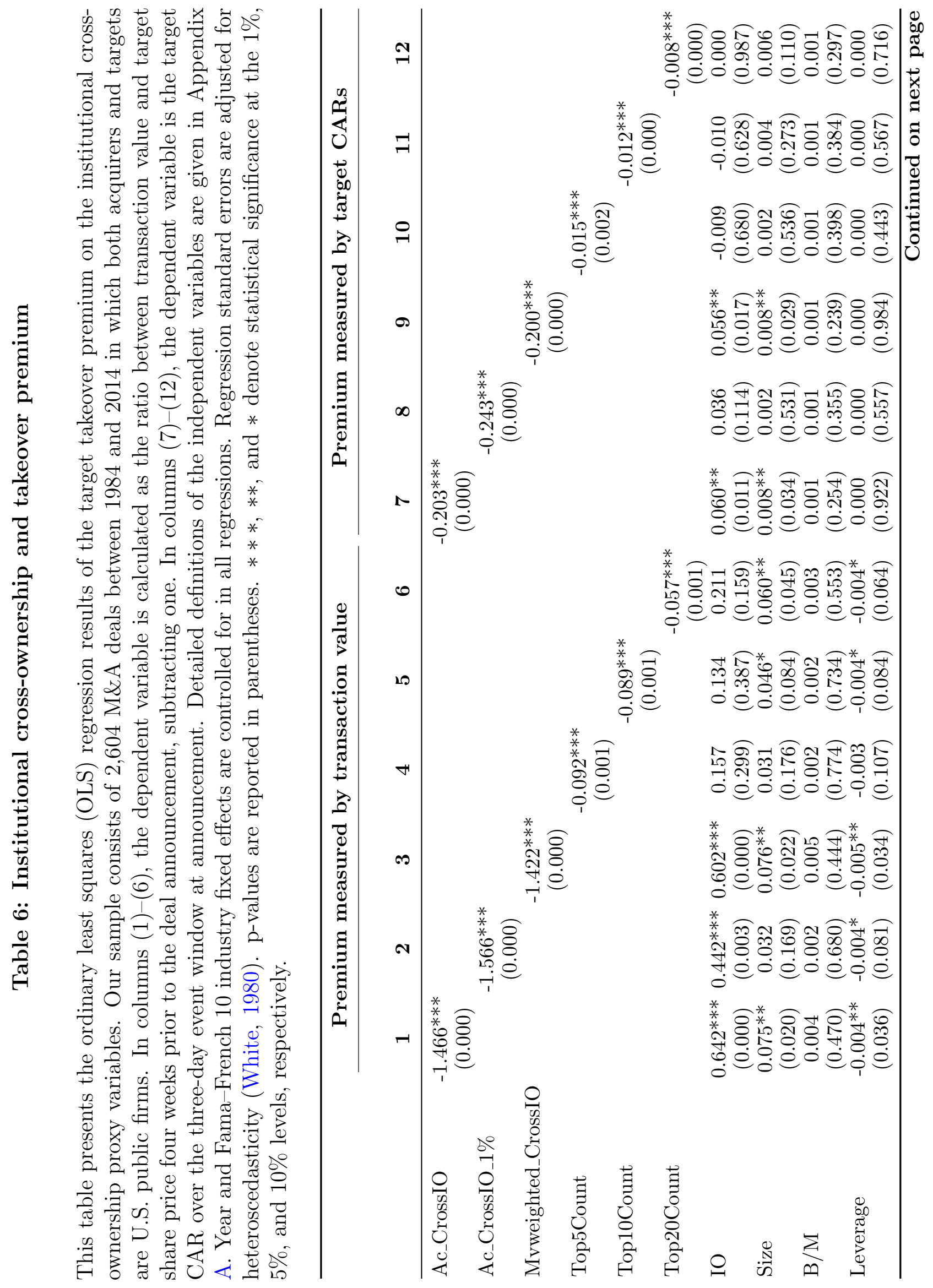




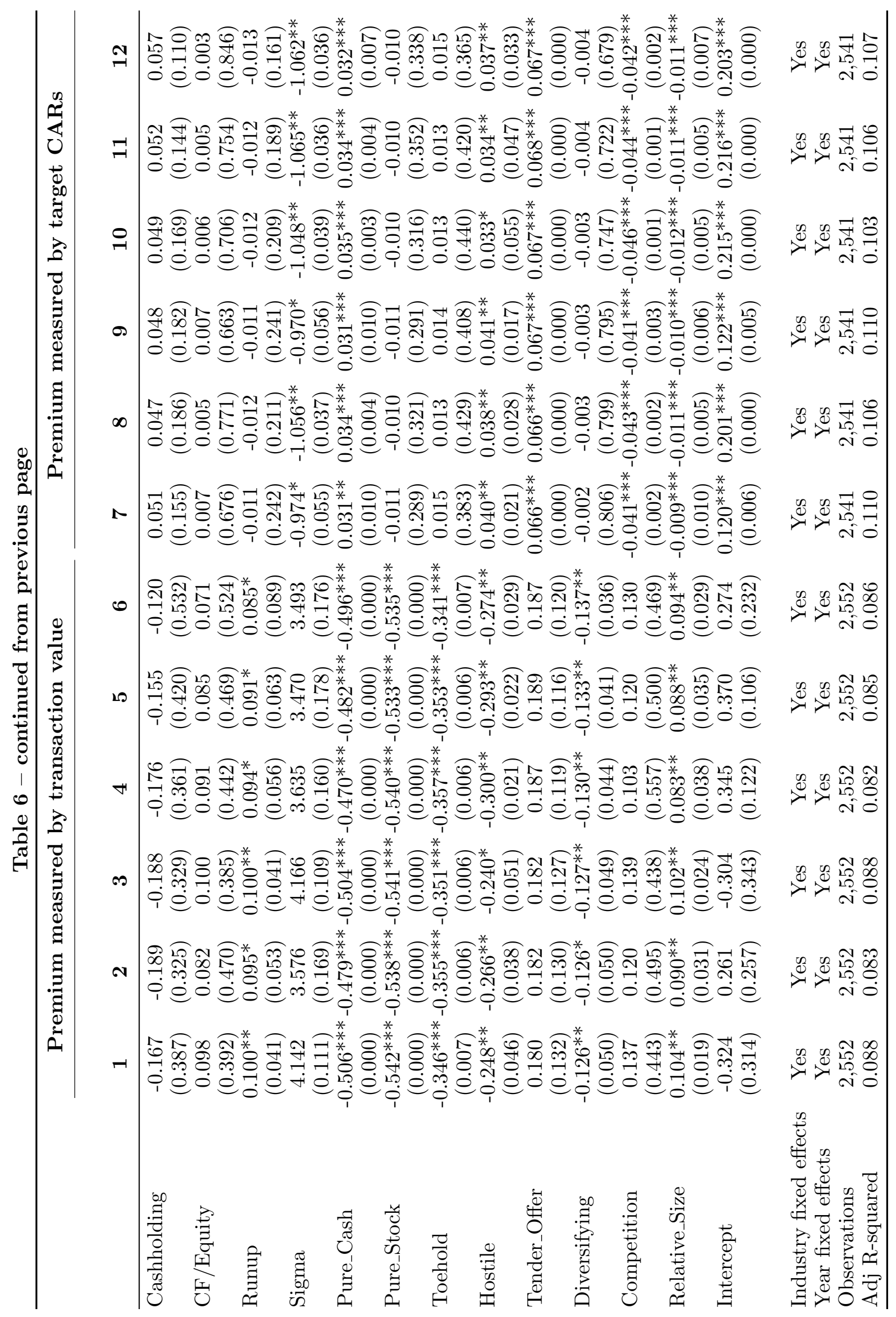




\section{Table 7: Institutional cross-ownership and method of payments}

This table presents the Tobit regression results of the acquirer method of payment on the institutional cross-ownership proxy variables. Our sample consists of 2,604 M\&A deals between 1984 and 2014 in which both acquirers and targets are U.S. public firms. The dependent variable is the percentage of stock defined as the percentage of stock payment involved in the total value of the transaction as reported by the Securities Data Company database. The Tobit regression adjusts for the left-censoring of observations at 0 . Detailed definitions of the independent variables are given in Appendix A. Year and Fama-French 10 industry fixed effects are controlled for in all regressions. Robust standard errors are estimated and p-values are reported in parentheses. $* * *, * *$, and $*$ denote statistical significance at the $1 \%, 5 \%$, and $10 \%$ levels, respectively.

\begin{tabular}{|c|c|c|c|c|c|c|}
\hline & 1 & 2 & 3 & 4 & 5 & 6 \\
\hline Ac_CrossIO & $\begin{array}{c}54.753^{* * *} \\
(0.000)\end{array}$ & & & & & \\
\hline Ac_CrossIO_1\% & & $72.634^{* * *}$ & & & & \\
\hline Mvweighted_CrossIO & & & $\begin{array}{c}53.189^{* * *} \\
(0.000)\end{array}$ & & & \\
\hline Top5Count & & & & $\begin{array}{c}5.396^{* * * *} \\
(0.000)\end{array}$ & & \\
\hline Top10Count & & & & & $\begin{array}{c}4.346^{* * *} \\
(0.000)\end{array}$ & \\
\hline Top20Count & & & & & & $\begin{array}{c}3.244^{* * *} \\
(0.000)\end{array}$ \\
\hline IO & $-20.970 * * *$ & $-15.453^{* * *}$ & $-19.456^{* * *}$ & -1.356 & -0.679 & -3.924 \\
\hline Size & $1.546^{*}$ & $3.061^{* * *}$ & $\left(\begin{array}{l}0.001) \\
1.486\end{array}\right.$ & $3.004^{* * *}$ & $2.339^{* * *}$ & $\begin{array}{l}(0.448) \\
1.227\end{array}$ \\
\hline $\mathrm{B} / \mathrm{M}$ & $\begin{array}{l}(0.087) \\
0.650^{*}\end{array}$ & $\begin{array}{l}(0.000) \\
0.707^{*}\end{array}$ & $\begin{array}{l}(0.105) \\
0.639^{*}\end{array}$ & $\begin{array}{l}(0.000) \\
0.730^{*}\end{array}$ & $\begin{array}{l}(0.005) \\
0.715^{*}\end{array}$ & $\begin{array}{l}(0.163) \\
0.636^{*}\end{array}$ \\
\hline & $(0.059)$ & $(0.060)$ & $(0.062)$ & $(0.054)$ & $(0.061)$ & $(0.069)$ \\
\hline Leverage & $\begin{array}{l}0.091 \\
(0.142)\end{array}$ & $\begin{array}{c}0.067 \\
(0.279)\end{array}$ & $\begin{array}{c}0.093 \\
(0.133)\end{array}$ & $\begin{array}{l}0.058 \\
(0.347)\end{array}$ & $\begin{array}{c}0.069 \\
(0.265)\end{array}$ & $\begin{array}{c}0.090 \\
(0.141)\end{array}$ \\
\hline Cashholding & $\begin{array}{l}8.561 \\
(0.278)\end{array}$ & $\begin{array}{l}10.164 \\
(0.201)\end{array}$ & $\begin{array}{r}9.183 \\
(0.245)\end{array}$ & $\begin{array}{r}9.860 \\
(0.216)\end{array}$ & $\begin{array}{l}8.172 \\
(0.303)\end{array}$ & $\begin{array}{l}5.282 \\
(0.504)\end{array}$ \\
\hline CF/Equity & $-9.231 * *$ & $\begin{array}{c}-8.716^{* *} \\
(0.029)\end{array}$ & $\begin{array}{l}-9.269^{* *} \\
(0020)\end{array}$ & $\begin{array}{l}-9.098^{* *} \\
(0.029)\end{array}$ & $-8.706^{* *}$ & $-7.860^{* *}$ \\
\hline Runup & $8.400 * * *$ & $8.639^{* * *}$ & $8.387^{* * *} *$ & 8. $609^{* * *}$ & $8.742^{* * * *}$ & $9.017^{* * *} *$ \\
\hline Sigma & $635.200^{* * *}$ & $659.176^{* * *}$ & $634.729 * * *$ & $660.403^{* * *}$ & $662.962^{* * *}$ & $658.333^{* * *}$ \\
\hline Collateral & $-20.031^{* * * *}$ & $-18.605^{* * * *}$ & $-20.607 * * *$ & $-18.524^{* * * *}$ & $-19.563^{* * * *}$ & $-20.912^{* * *}$ \\
\hline Toehold & $-15.385^{* *}$ & $-15.072^{* * *}$ & $-15.113^{* *}$ & $-15.312^{* *}$ & $-15.365^{* *}$ & $\begin{aligned} &(0.003) \\
&-15.624^{* *}\end{aligned}$ \\
\hline Hostile & $-13.177^{*}$ & -12.581 & $\begin{array}{l}(0.023) \\
-13.340^{*}\end{array}$ & $\begin{array}{l}(0.022) \\
-11.079\end{array}$ & $\begin{array}{l}(0.022) \\
-11.653\end{array}$ & $\begin{array}{l}(0.018) \\
-12.408\end{array}$ \\
\hline Tondon & & $(0.110)_{* *}$ & $(0.086)_{* *}$ & $(0.164)_{* *}$ & $(0.138)$ & $(0.115)_{* *}$ \\
\hline Tender_Offer & $\begin{array}{c}-80.409^{* * *} \\
(0.000)\end{array}$ & $\begin{array}{c}-80.620 * * * \\
(0.000)\end{array}$ & $\begin{array}{c}-80.533^{* * *} \\
(0.000)\end{array}$ & $\begin{array}{c}-80.724^{* * *} \\
(0.000)\end{array}$ & $\begin{array}{c}-80.502^{* * *} \\
(0.000)\end{array}$ & $\begin{array}{l}-79.719 * * * \\
(0.000)\end{array}$ \\
\hline Diversifying & $-4.346^{*}$ & $-4.250^{*}$ & $-4.336^{*}$ & -3.925 & -3.815 & -3.606 \\
\hline Competition & $\begin{array}{l}(0.090) \\
-6.608\end{array}$ & $\begin{array}{l}(0.098) \\
-5.897\end{array}$ & $\begin{array}{l}(0.091) \\
-6.652\end{array}$ & $\begin{array}{l}(0.127) \\
-4954\end{array}$ & $\begin{array}{l}(0.136) \\
-5.720\end{array}$ & $(0.157)$ \\
\hline & $(0.166)$ & $(0.218)_{*}$ & $(0.164)$ & $(0.304)_{*}$ & $(0.233)$ & $(0.171)$ \\
\hline Premium & $-1.810^{*}$ & $-1.935^{* *}$ & $-1.814^{*}$ & $-1.989^{* *}$ & $-1.853^{*}$ & $-1.753^{*}$ \\
\hline Relative_Size & -2.300 & $\begin{array}{l}-1.044) \\
-1.808\end{array}$ & -2.197 & -1.524 & -1.798 & -2.232 \\
\hline Intercept & $\begin{array}{c}(0.118) \\
31.350^{* *} \\
(0.010)\end{array}$ & $\begin{array}{c}(0.168) \\
8.956 \\
(0.433)\end{array}$ & $\begin{array}{c}(0.140) \\
30.818^{* *} \\
(0.012)\end{array}$ & $\begin{array}{c}(0.209) \\
3.152 \\
(0.782)\end{array}$ & $\begin{array}{c}(0.174) \\
3.863 \\
(0.734)\end{array}$ & $\begin{array}{l}(0.124) \\
10.034 \\
(0.381)\end{array}$ \\
\hline Industry \& Year fixed effects & Yes & Yes & Yes & Yes & Yes & Yes \\
\hline $\begin{array}{l}\text { as } \\
\text { guared }\end{array}$ & $\begin{array}{l}2,478 \\
0.064\end{array}$ & $\begin{array}{l}2,478 \\
0.063\end{array}$ & 2,478 & 2,478 & 2,478 & 2,478 \\
\hline s tared & & & & & & \\
\hline
\end{tabular}



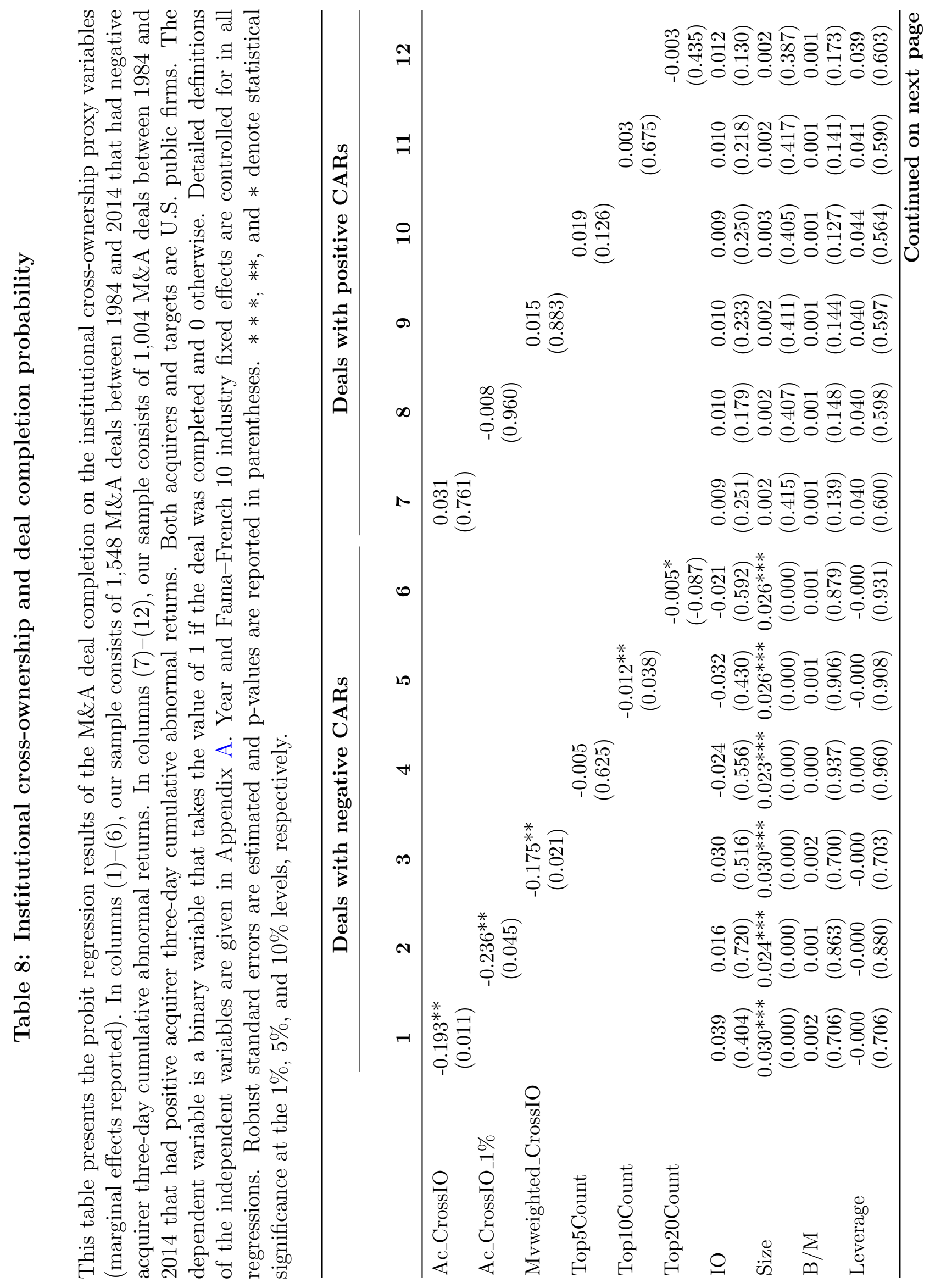


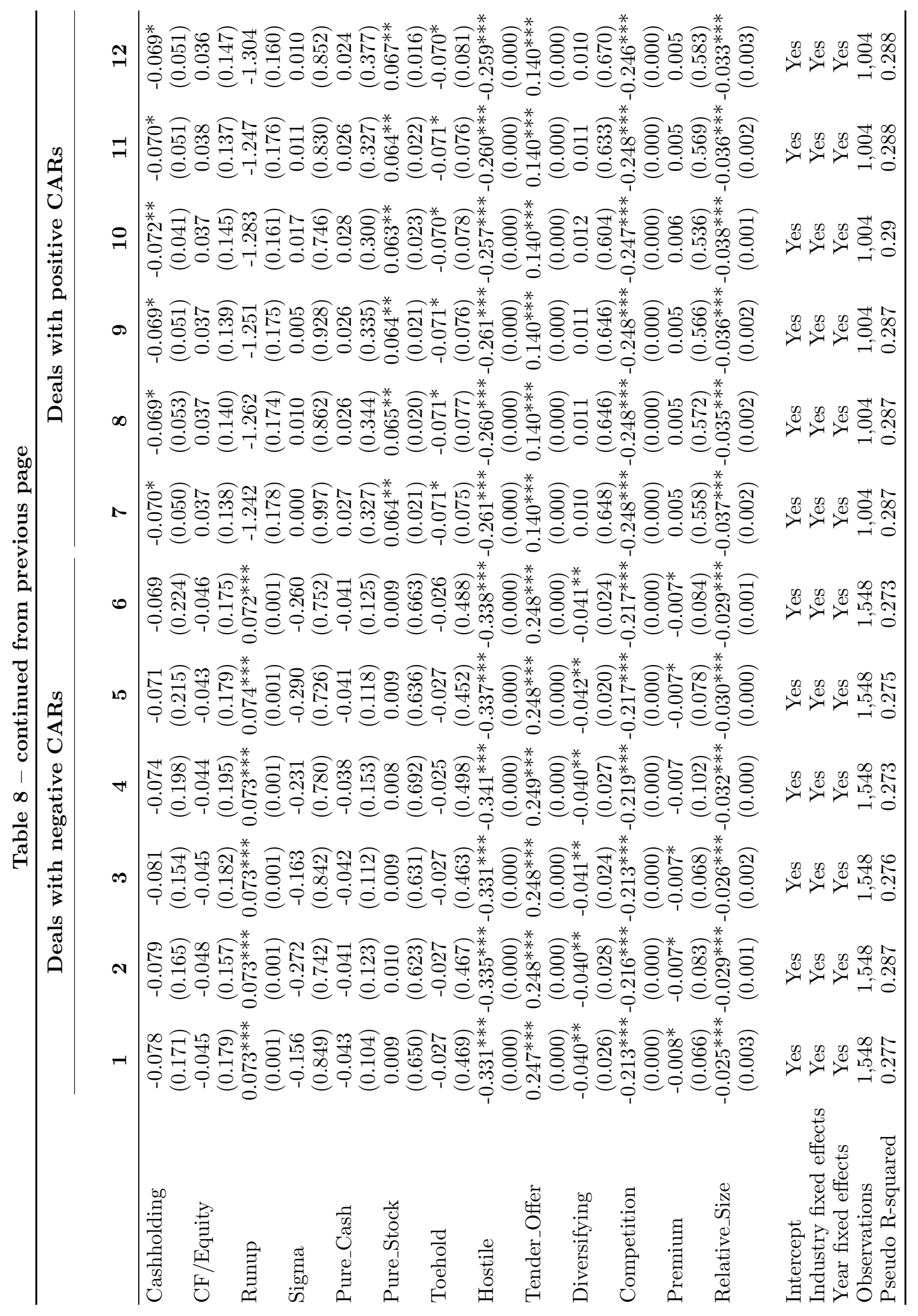




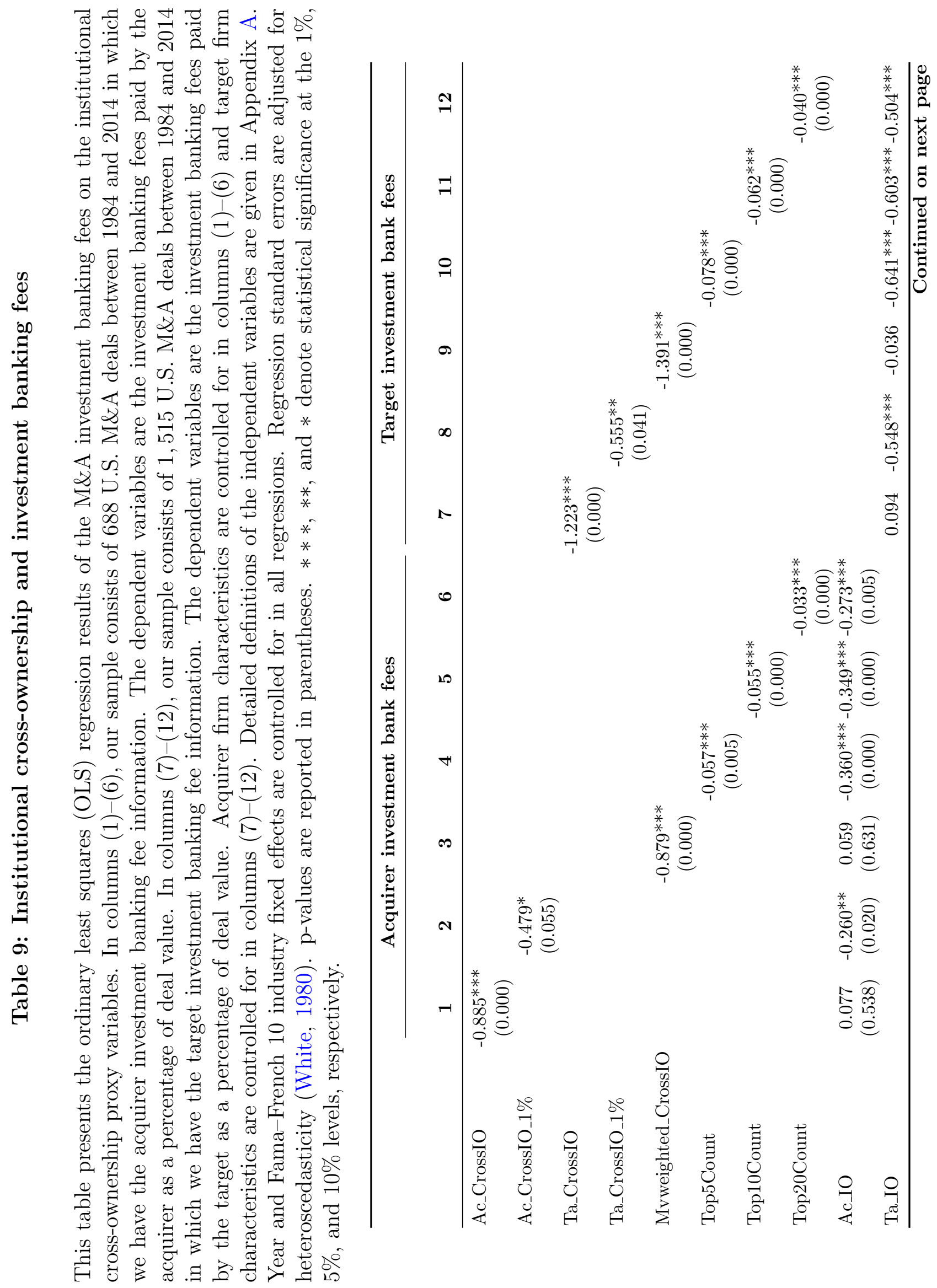




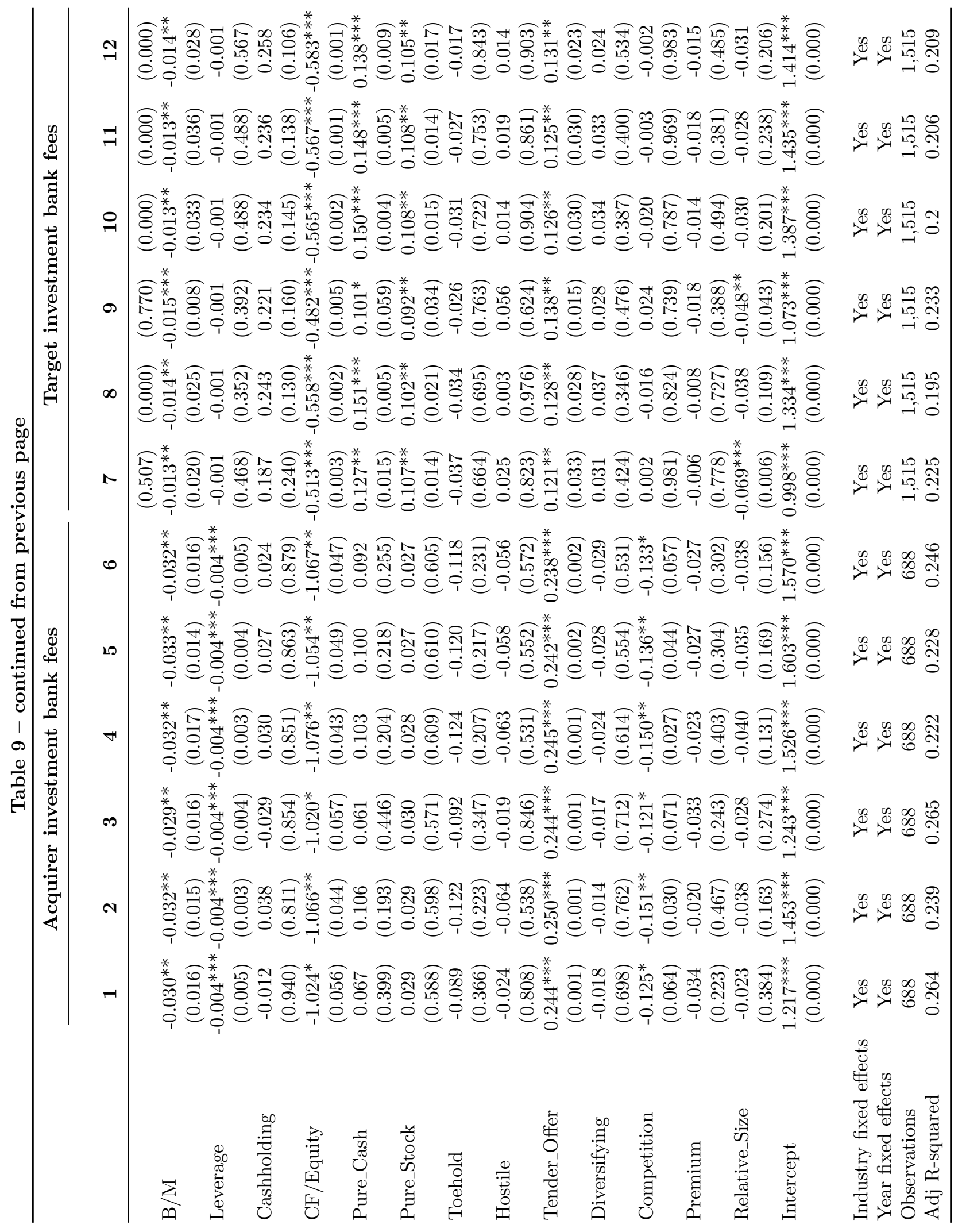


Table 10: Institutional cross-ownership and earnings restatement

This table presents the coefficient estimates (marginal effects reported) from probit regressions of earnings misreporting. Only completed M\&A deals are included in these regressions. The dependent variable is equal to one if the beginning date of the misstatement period falls within a two-year window before the merger completion and zero otherwise. We control for acquirer, target, and deal characteristics. Detailed definitions of the independent variables can be found in Appendix A. Year and Fama-French 10 industry fixed effects are controlled for in all regressions. Robust standard errors are clustered at the deal level. p-values are reported in parentheses. Significance at the $0.01,0.05$, and 0.10 levels is indicated by $* * *, * *$, and $*$, respectively.

\begin{tabular}{|c|c|c|c|c|c|c|c|c|}
\hline & 1 & 2 & 3 & 4 & 5 & 6 & 7 & 8 \\
\hline Ac_CrossIO & $\begin{array}{c}-0.132^{*} \\
(0.066)\end{array}$ & & & & & & & \\
\hline Ac_CrossIO_1\% & & $\begin{array}{c}-0.251^{* *} \\
(0.022)\end{array}$ & & & & & & \\
\hline Ta_CrossIO & & & $\begin{array}{c}-0.141^{* *} \\
(0.034)\end{array}$ & & & & & \\
\hline Ta_CrossIO_1\% & & & & $\begin{array}{c}-0.331^{* * *} \\
(0.002)\end{array}$ & & & & \\
\hline Mvweighted_CrossIO & & & & & $\begin{array}{c}-0.174^{* *} \\
(0.019)\end{array}$ & & & \\
\hline Top5Count & & & & & & $\begin{array}{c}-0.028^{* * *} \\
(0.001)\end{array}$ & & \\
\hline Top10Count & & & & & & & $\begin{array}{c}-0.013^{* *} \\
(0.012)\end{array}$ & \\
\hline Top20Count & & & & & & & & $\begin{array}{c}-0.008^{* * *} \\
(0.009)\end{array}$ \\
\hline $\mathrm{IO}$ & $\begin{array}{c}0.093^{* *} \\
(0.016)\end{array}$ & $\begin{array}{c}0.095^{* * *} \\
(0.007)\end{array}$ & $\begin{array}{c}0.065^{*} \\
(0.055)\end{array}$ & $\begin{array}{c}0.088^{* * *} \\
(0.010)\end{array}$ & $\begin{array}{c}0.096^{* *} \\
(0.011)\end{array}$ & $\begin{array}{c}0.046 \\
(0.175)\end{array}$ & $\begin{array}{c}0.048 \\
(0.155)\end{array}$ & $\begin{array}{c}0.052 \\
(0.124)\end{array}$ \\
\hline Size & $\begin{array}{l}-0.005 \\
(0.622)\end{array}$ & $\begin{array}{l}-0.015 \\
(0.156)\end{array}$ & $\begin{array}{l}-0.000 \\
(0.981)\end{array}$ & $\begin{array}{c}-0.014 \\
(0.150)\end{array}$ & $\begin{array}{c}-0.005 \\
(0.614)\end{array}$ & $\begin{array}{l}-0.006 \\
(0.564)\end{array}$ & $\begin{array}{l}-0.005 \\
(0.608)\end{array}$ & $\begin{array}{l}-0.006 \\
(0.563)\end{array}$ \\
\hline Leverage & $\begin{array}{l}-0.000 \\
(0.811)\end{array}$ & $\begin{array}{l}-0.000 \\
(0.575)\end{array}$ & $\begin{array}{l}-0.000 \\
(0.790)\end{array}$ & $\begin{array}{l}-0.000 \\
(0.576)\end{array}$ & $\begin{array}{l}-0.000 \\
(0.810)\end{array}$ & $\begin{array}{l}-0.000 \\
(0.868)\end{array}$ & $\begin{array}{l}-0.000 \\
(0.814)\end{array}$ & $\begin{array}{c}-0.000 \\
(0.810)\end{array}$ \\
\hline $\mathrm{B} / \mathrm{M}$ & $\begin{array}{c}-0.004^{*} \\
(0.078)\end{array}$ & $\begin{array}{c}-0.004^{*} \\
(0.083)\end{array}$ & $\begin{array}{c}-0.004^{*} \\
(0.095)\end{array}$ & $\begin{array}{c}-0.004^{*} \\
(0.097)\end{array}$ & $\begin{array}{c}-0.004^{*} \\
(0.072)\end{array}$ & $\begin{array}{c}-0.004^{*} \\
(0.076)\end{array}$ & $\begin{array}{c}-0.004^{*} \\
(0.078)\end{array}$ & $\begin{array}{l}-0.004 \\
(0.101)\end{array}$ \\
\hline Runup & $\begin{array}{c}0.037^{* * *} \\
(0.003)\end{array}$ & $\begin{array}{c}0.036^{* * *} \\
(0.006)\end{array}$ & $\begin{array}{c}0.036^{* * *} \\
(0.004)\end{array}$ & $\begin{array}{c}0.035^{* * *} \\
(0.006)\end{array}$ & $\begin{array}{c}0.037^{* * *} \\
(0.003)\end{array}$ & $\begin{array}{c}0.036^{* * *} \\
(0.004)\end{array}$ & $\begin{array}{c}0.036^{* * *} \\
(0.005)\end{array}$ & $\begin{array}{c}0.035^{* * *} * \\
(0.006)\end{array}$ \\
\hline Sigma & $\begin{array}{c}0.913 \\
(0.201)\end{array}$ & $\begin{array}{c}0.851 \\
(0.250)\end{array}$ & $\begin{array}{c}0.898 \\
(0.207)\end{array}$ & $\begin{array}{c}0.838 \\
(0.254)\end{array}$ & $\begin{array}{c}0.898 \\
(0.208)\end{array}$ & $\begin{array}{c}0.845 \\
(0.235)\end{array}$ & $\begin{array}{c}0.854 \\
(0.226)\end{array}$ & $\begin{array}{c}0.861 \\
(0.220)\end{array}$ \\
\hline Pure_Stock & $\begin{array}{c}0.019 \\
(0.218)\end{array}$ & $\begin{array}{l}0.027^{*} \\
(0.093)\end{array}$ & $\begin{array}{c}0.021 \\
(0.177)\end{array}$ & $\begin{array}{l}0.028^{*} \\
(0.075)\end{array}$ & $\begin{array}{c}0.020 \\
(0.199)\end{array}$ & $\begin{array}{c}0.022 \\
(0.160)\end{array}$ & $\begin{array}{c}0.020 \\
(0.205)\end{array}$ & $\begin{array}{c}0.020 \\
(0.211)\end{array}$ \\
\hline Toehold & $\begin{array}{l}-0.028 \\
(0.585)\end{array}$ & $\begin{array}{l}-0.029 \\
(0.572)\end{array}$ & $\begin{array}{l}-0.027 \\
(0.603)\end{array}$ & $\begin{array}{l}-0.027 \\
(0.603)\end{array}$ & $\begin{array}{l}-0.029 \\
(0.574)\end{array}$ & $\begin{array}{l}-0.019 \\
(0.710)\end{array}$ & $\begin{array}{l}-0.025 \\
(0.624)\end{array}$ & $\begin{array}{l}-0.027 \\
(0.598)\end{array}$ \\
\hline Hostile & $\begin{array}{c}0.053 \\
(0.399)\end{array}$ & $\begin{array}{c}0.047 \\
(0.457)\end{array}$ & $\begin{array}{l}0.051 \\
(0.424)\end{array}$ & $\begin{array}{c}0.048 \\
(0.443)\end{array}$ & $\begin{array}{c}0.053 \\
(0.399)\end{array}$ & $\begin{array}{c}0.043 \\
(0.500)\end{array}$ & $\begin{array}{c}0.051 \\
(0.423)\end{array}$ & $\begin{array}{l}0.050 \\
(0.437)\end{array}$ \\
\hline Tender_Offer & $\begin{array}{l}-0.025 \\
(0.255)\end{array}$ & $\begin{array}{c}-0.030 \\
(0.182)\end{array}$ & $\begin{array}{l}-0.027 \\
(0.225)\end{array}$ & $\begin{array}{l}-0.028 \\
(0.212)\end{array}$ & $\begin{array}{l}-0.025 \\
(0.251)\end{array}$ & $\begin{array}{l}-0.023 \\
(0.279)\end{array}$ & $\begin{array}{l}-0.024 \\
(0.272)\end{array}$ & $\begin{array}{l}-0.025 \\
(0.241)\end{array}$ \\
\hline Diversifying & $\begin{array}{l}-0.011 \\
(0.471)\end{array}$ & $\begin{array}{l}-0.012 \\
(0.435)\end{array}$ & $\begin{array}{l}-0.011 \\
(0.463)\end{array}$ & $\begin{array}{l}-0.014 \\
(0.377)\end{array}$ & $\begin{array}{l}-0.011 \\
(0.468)\end{array}$ & $\begin{array}{l}-0.013 \\
(0.411)\end{array}$ & $\begin{array}{l}-0.012 \\
(0.438)\end{array}$ & $\begin{array}{l}-0.013 \\
(0.404)\end{array}$ \\
\hline Competition & $\begin{array}{c}0.031 \\
(0.309)\end{array}$ & $\begin{array}{c}0.038 \\
(0.220)\end{array}$ & $\begin{array}{c}0.032 \\
(0.307)\end{array}$ & $\begin{array}{c}0.035 \\
(0.263)\end{array}$ & $\begin{array}{c}0.031 \\
(0.309)\end{array}$ & $\begin{array}{c}0.027 \\
(0.380)\end{array}$ & $\begin{array}{c}0.030 \\
(0.337)\end{array}$ & $\begin{array}{c}0.030 \\
(0.336)\end{array}$ \\
\hline Premium & $\begin{array}{l}-0.001 \\
(0.862)\end{array}$ & $\begin{array}{c}0.012^{* * * *} \\
(0.001)\end{array}$ & $\begin{array}{l}-0.000 \\
(0.959)\end{array}$ & $\begin{array}{c}0.012^{* * *} \\
(0.001)\end{array}$ & $\begin{array}{l}-0.001 \\
(0.915)\end{array}$ & $\begin{array}{l}-0.001 \\
(0.860)\end{array}$ & $\begin{array}{l}-0.002 \\
(0.817)\end{array}$ & $\begin{array}{l}-0.001 \\
(0.933)\end{array}$ \\
\hline Relative_Size & $\begin{array}{l}-0.015 \\
(0.342)\end{array}$ & $\begin{array}{c}-0.024 \\
(0.152)\end{array}$ & $\begin{array}{l}-0.013 \\
(0.376)\end{array}$ & $\begin{array}{l}-0.023 \\
(0.156)\end{array}$ & $\begin{array}{l}-0.015 \\
(0.322)\end{array}$ & $\begin{array}{l}-0.014 \\
(0.335)\end{array}$ & $\begin{array}{l}-0.015 \\
(0.323)\end{array}$ & $\begin{array}{l}-0.016 \\
(0.297)\end{array}$ \\
\hline Industry fixed effects & Yes & & & & & Yes & & \\
\hline Year fixed effects & Yes & Yes & Yes & Yes & Yes & Yes & Yes & Yes \\
\hline & 1,542 & 1,542 & 1,542 & 1,542 & 1,542 & 1,542 & 1,542 & 1,542 \\
\hline Pseudo R-squared & 0.088 & 0.090 & 0.089 & 0.089 & 0.097 & 0.096 & 0.092 & 0.092 \\
\hline
\end{tabular}




\section{Table 11: Institutional cross-ownership and deal synergies}

Panel A. Ordinary least squares (OLS) regressions. This panel presents the OLS regression results of the deal synergies on the institutional cross-ownership proxy variables. Our sample consists of 2,604 M\&A deals between 1984 and 2014 in which both acquirers and targets are U.S. public firms. Following Bradley et al. (1988) and Harford et al. (2011), the dependent variable Synergies_percent is calculated as: (acquirer CAR3 $*$ acquirer market value + target CAR3 * (1-toehold)*target market value)/ (acquirer market value + (1-toehold)*target market value). The primary explanatory variables of interest are the number of top 10 institutional cross-ownership proxy variables. In columns (2) and (3), we divide the top 10 institutional crossowners into independent institutional investors and grey institutional investors. In columns (4) and (5), we divide the top 10 institutional cross-owners into dedicated/quasi-index institutional investors and transient institutional investors. Detailed definitions of the control variables are given in Appendix A. Year and Fama-French 10 industry fixed effects are controlled for in all regressions. Regression standard errors are adjusted for heteroscedasticity (White, 1980). p-values are reported in parentheses. $* * *, * *$ and $*$ denote statistical significance at the $1 \%$, $5 \%$ and $10 \%$ levels, respectively.

\begin{tabular}{|c|c|c|c|c|c|}
\hline & 1 & 2 & 3 & 4 & 5 \\
\hline Top10Count & $\begin{array}{l}0.020^{*} \\
(0.059)\end{array}$ & & & & \\
\hline Top10CountIndependent & & $\begin{array}{c}0.029 * * \\
(0.038)\end{array}$ & & & \\
\hline Top10CountGrey & & & $\begin{array}{c}0.009 \\
(0.560)\end{array}$ & & \\
\hline Top10CountDedicated/Quasi-index & & & & $\begin{array}{c}0.025^{* *} \\
(0.028)\end{array}$ & \\
\hline Top10CountTransient & & & & & $\begin{array}{l}-0.008 \\
(0.766)\end{array}$ \\
\hline $\mathrm{IO}$ & $\begin{array}{l}-0.011 \\
(0.881)\end{array}$ & $\begin{array}{c}-0.031 \\
(0.654)\end{array}$ & $\begin{array}{l}-0.019 \\
(0.792)\end{array}$ & $\begin{array}{l}-0.002 \\
(0.975)\end{array}$ & $\begin{array}{l}-0.026 \\
(0.708)\end{array}$ \\
\hline Size & $\begin{array}{c}0.004 \\
(0.740)\end{array}$ & $\begin{array}{c}0.007 \\
(0.545)\end{array}$ & $\begin{array}{c}0.007 \\
(0.517)\end{array}$ & $\begin{array}{c}0.003 \\
(0.793)\end{array}$ & $\begin{array}{c}0.009 \\
(0.396)\end{array}$ \\
\hline $\mathrm{B} / \mathrm{M}$ & $\begin{array}{l}-0.001 \\
(0.898)\end{array}$ & $\begin{array}{c}-0.001 \\
(0.873)\end{array}$ & $\begin{array}{l}-0.001 \\
(0.921)\end{array}$ & $\begin{array}{l}-0.000 \\
(0.943)\end{array}$ & $\begin{array}{l}-0.001 \\
(0.932)\end{array}$ \\
\hline Leverage & $\begin{array}{c}0.000 \\
(0.592)\end{array}$ & $\begin{array}{c}0.000 \\
(0.601)\end{array}$ & $\begin{array}{c}0.000 \\
(0.680)\end{array}$ & $\begin{array}{c}0.000 \\
(0.614)\end{array}$ & $\begin{array}{c}0.000 \\
(0.718)\end{array}$ \\
\hline Cashholding & $\begin{array}{l}-0.062 \\
(0.543)\end{array}$ & $\begin{array}{l}-0.055 \\
(0.590)\end{array}$ & $\begin{array}{l}-0.063 \\
(0.539)\end{array}$ & $\begin{array}{l}-0.065 \\
(0.528)\end{array}$ & $\begin{array}{l}-0.061 \\
(0.550)\end{array}$ \\
\hline $\mathrm{CF} /$ Equity & $\begin{array}{c}0.018 \\
(0.751)\end{array}$ & $\begin{array}{c}0.020 \\
(0.727)\end{array}$ & $\begin{array}{c}0.019 \\
(0.742)\end{array}$ & $\begin{array}{c}0.018 \\
(0.755)\end{array}$ & $\begin{array}{c}0.019 \\
(0.733)\end{array}$ \\
\hline Runup & $\begin{array}{l}-0.036 \\
(0.255)\end{array}$ & $\begin{array}{c}-0.039 \\
(0.211)\end{array}$ & $\begin{array}{l}-0.034 \\
(0.272)\end{array}$ & $\begin{array}{l}-0.033 \\
(0.286)\end{array}$ & $\begin{array}{l}-0.035 \\
(0.269)\end{array}$ \\
\hline Sigma & $\begin{array}{c}1.196 \\
(0.418)\end{array}$ & $\begin{array}{c}1.129 \\
(0.445)\end{array}$ & $\begin{array}{l}1.178 \\
(0.426)\end{array}$ & $\begin{array}{c}1.208 \\
(0.413)\end{array}$ & $\begin{array}{c}1.153 \\
(0.436)\end{array}$ \\
\hline Pure_Cash & $0.080^{*}$ & $0.080^{* *}$ & $0.075^{*}$ & $0.079^{*}$ & $0.074 *$ \\
\hline
\end{tabular}

Continued on next page 
Table 11 Panel A - continued from previous page

\begin{tabular}{|c|c|c|c|c|c|}
\hline & 1 & 2 & 3 & 4 & 5 \\
\hline & $(0.050)$ & $(0.050)$ & $(0.064)$ & $(0.052)$ & $(0.068)$ \\
\hline \multirow[t]{2}{*}{ Pure_Stock } & -0.020 & -0.020 & -0.018 & -0.020 & -0.017 \\
\hline & $(0.565)$ & $(0.575)$ & $(0.611)$ & $(0.565)$ & $(0.631)$ \\
\hline \multirow[t]{2}{*}{ Toehold } & -0.098 & -0.100 & -0.097 & -0.095 & -0.096 \\
\hline & $(0.125)$ & $(0.118)$ & $(0.130)$ & $(0.136)$ & $(0.131)$ \\
\hline \multirow[t]{2}{*}{ Hostile } & 0.045 & 0.044 & 0.047 & 0.043 & 0.047 \\
\hline & $(0.521)$ & $(0.526)$ & $(0.502)$ & $(0.534)$ & $(0.503)$ \\
\hline \multirow[t]{2}{*}{ Tender_Offer } & 0.015 & 0.015 & 0.014 & 0.014 & 0.013 \\
\hline & $(0.744)$ & $(0.744)$ & $(0.763)$ & $(0.759)$ & $(0.774)$ \\
\hline \multirow[t]{2}{*}{ Diversifying } & -0.008 & -0.010 & -0.010 & -0.009 & -0.011 \\
\hline & $(0.791)$ & $(0.749)$ & $(0.759)$ & $(0.775)$ & $(0.735)$ \\
\hline \multirow[t]{2}{*}{ Competition } & $0.094^{*}$ & $0.097^{*}$ & $0.095^{*}$ & $0.091^{*}$ & $0.097^{*}$ \\
\hline & $(0.063)$ & $(0.053)$ & $(0.059)$ & $(0.070)$ & $(0.055)$ \\
\hline \multirow[t]{2}{*}{ Relative_Size } & 0.008 & 0.009 & 0.010 & 0.008 & 0.010 \\
\hline & $(0.482)$ & $(0.460)$ & $(0.411)$ & $(0.481)$ & $(0.383)$ \\
\hline \multirow[t]{2}{*}{ Intercept } & -0.062 & -0.036 & -0.053 & -0.027 & -0.043 \\
\hline & $(0.671)$ & $(0.805)$ & $(0.722)$ & $(0.853)$ & $(0.767)$ \\
\hline Industry fixed effects & Yes & Yes & Yes & Yes & Yes \\
\hline Year fixed effects & Yes & Yes & Yes & Yes & Yes \\
\hline Observations & 2,529 & 2,529 & 2,529 & 2,529 & 2,529 \\
\hline Adj R-squared & 0.027 & 0.026 & 0.028 & 0.026 & 0.028 \\
\hline
\end{tabular}




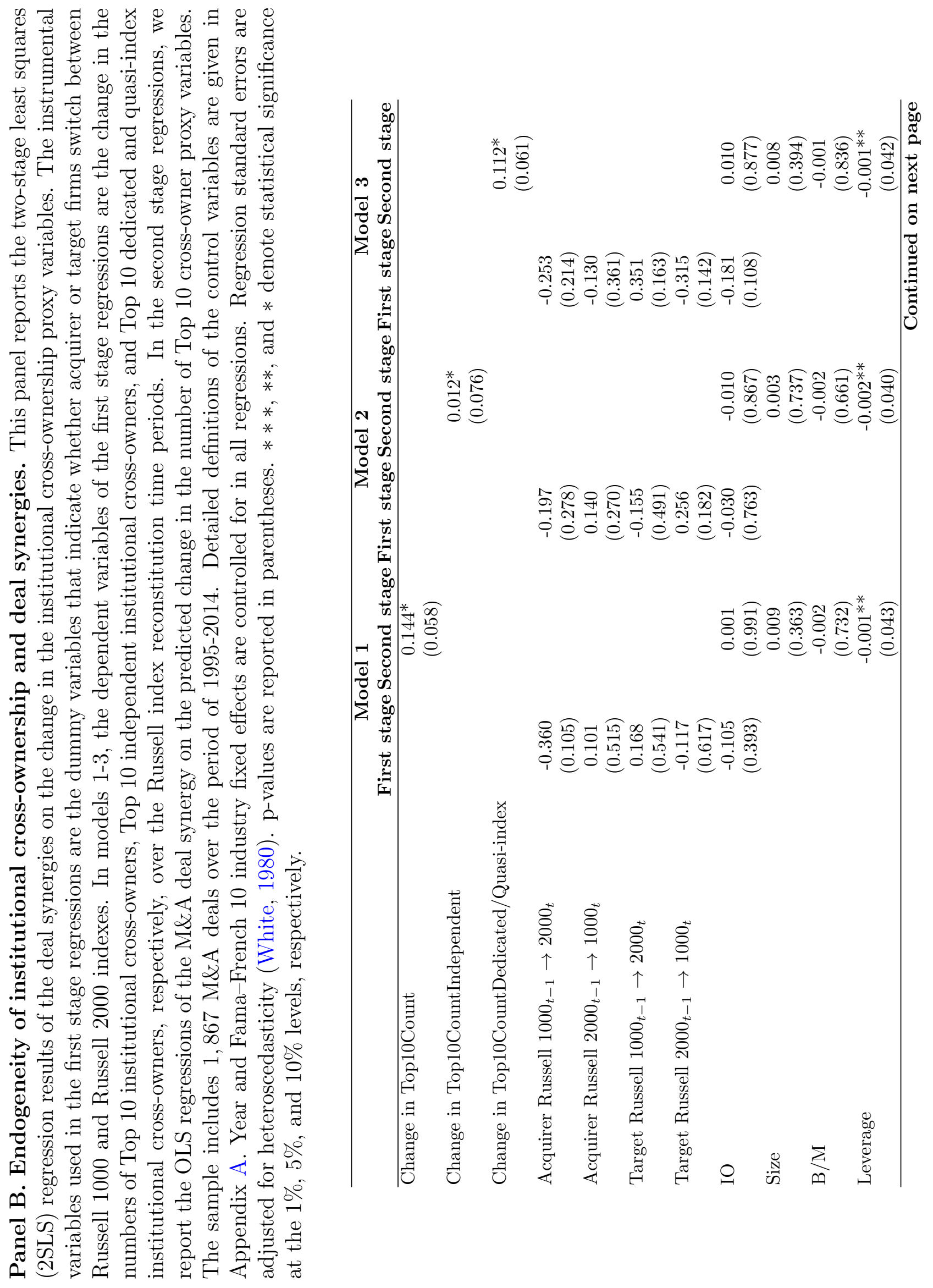




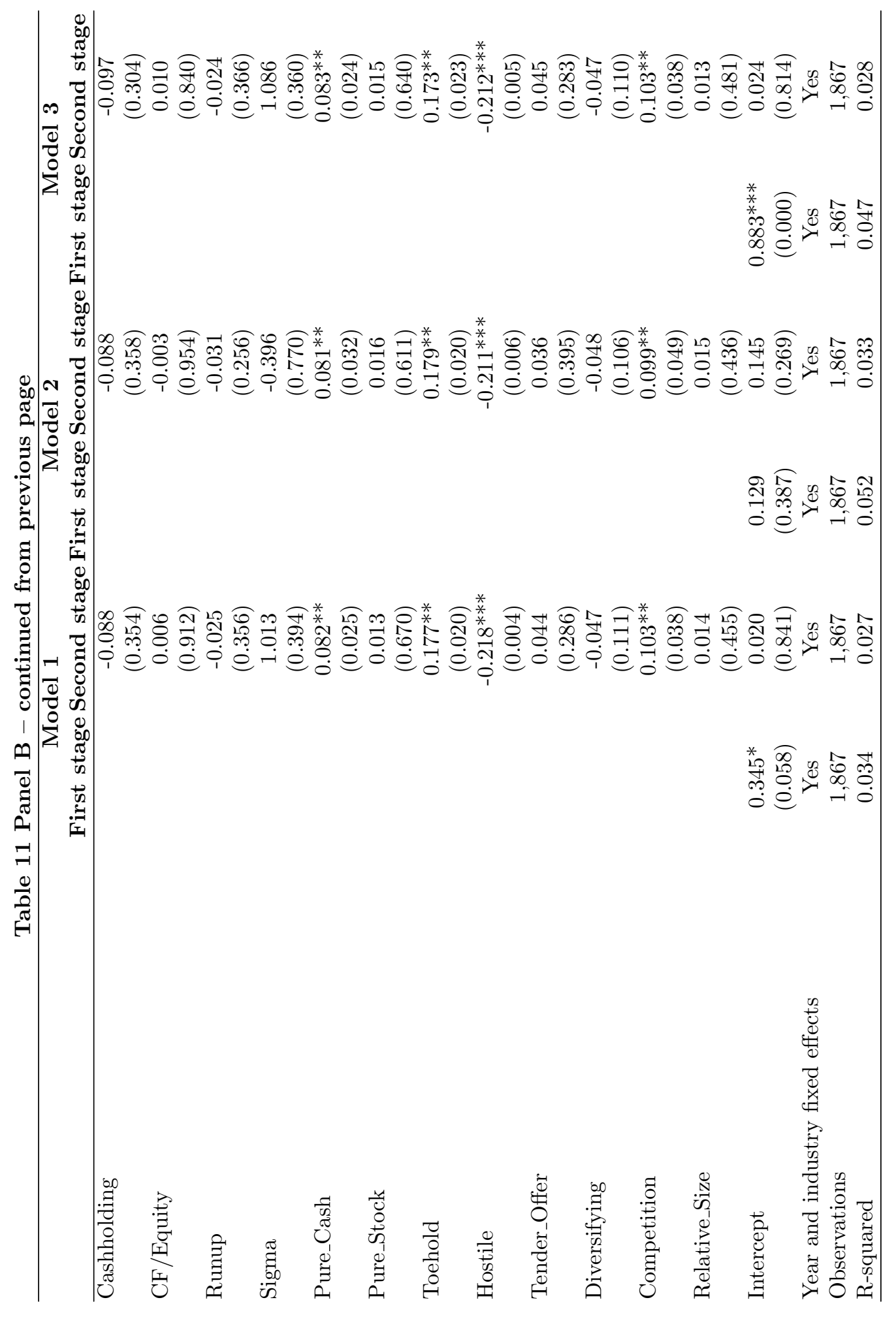




\section{Table 12: Institutional cross-ownership and deal long-run performance}

This table presents the regression results of acquirer long-run operating and stock performance on institutional cross-ownership characteristics. The OLS regressions are based on a sample of 2,604 M\&A deals that are carried out by U.S. public firms between 1984 and 2014 and have available observations for the regressions. Following Huson et al. (2004), Guercio et al. (2008) and Duchin and Schmidt (2013), we compute three year changes in operating return on assets ( $\left.\triangle \mathrm{AROA} \_3 \mathrm{Y}\right)$ to measure acquirer long-run operating performance after the deal announcement. Following Barber and Lyon (1996), AROA is adjusted for the median AROA of a controlled group in which all firms are in the same industry (two-digit SIC code) and have similar previous ROA $( \pm 10 \%)$ in the fiscal year preceding the deal announcement. Following Barber and Lyon (1997) and Lyon et al. (1999), we compute acquirer three year buy-and-hold abnormal stock returns (BHAR_3Y) after the deal announcement with the benchmark being the return of a control firm stock in the same industry (two-digit SIC code), of similar size ( \pm $30 \%$ ), with the nearest book-to-market ratio. The primary explanatory variables of interest are the numbers of top 10 institutional cross-owners. Detailed definitions of all variables can be found in Appendix A. Year and Fama-French 10 industry fixed effects are controlled for in all regressions. Regression standard errors are adjusted for heteroscedasticity (White, 1980). p-values are reported in parentheses. Significance at the 0.01, 0.05, and 0.10 levels is indicated by $* * *, * *$, and $*$, respectively.

\begin{tabular}{|c|c|c|c|c|c|c|}
\hline & \multicolumn{3}{|c|}{$\triangle$ AROA_3Y } & \multicolumn{3}{|c|}{ BHAR $\_3 Y$} \\
\hline & 1 & 2 & 3 & 4 & 5 & 6 \\
\hline Top10Count & $\begin{array}{c}0.005^{* *} \\
(0.020)\end{array}$ & & & $\begin{array}{c}0.002^{* *} \\
(0.015)\end{array}$ & & \\
\hline Top10CountIndependent & & $\begin{array}{c}0.007^{* *} \\
(0.034)\end{array}$ & & & $\begin{array}{c}0.003^{* * *} \\
(0.004)\end{array}$ & \\
\hline Top10CountDedicated/Quasi-index & & & $\begin{array}{l}0.004^{*} \\
(0.082)\end{array}$ & & & $\begin{array}{c}0.002^{* *} \\
(0.024)\end{array}$ \\
\hline $\mathrm{IO}$ & $\begin{array}{l}0.029^{*} \\
(0.056)\end{array}$ & $\begin{array}{c}0.025 \\
(0.109)\end{array}$ & $\begin{array}{l}0.029^{*} \\
(0.059)\end{array}$ & $\begin{array}{c}0.006 \\
(0.222)\end{array}$ & $\begin{array}{c}0.004 \\
(0.383)\end{array}$ & $\begin{array}{c}0.006 \\
(0.197)\end{array}$ \\
\hline Size & $\begin{array}{l}-0.003 \\
(0.204)\end{array}$ & $\begin{array}{c}-0.002 \\
(0.363)\end{array}$ & $\begin{array}{l}-0.003 \\
(0.277)\end{array}$ & $\begin{array}{c}-0.002^{* *} \\
(0.013)\end{array}$ & $\begin{array}{c}-0.002^{* *} \\
(0.024)\end{array}$ & $\begin{array}{c}-0.002^{* *} \\
(0.016)\end{array}$ \\
\hline $\mathrm{B} / \mathrm{M}$ & $\begin{array}{l}-0.001 \\
(0.384)\end{array}$ & $\begin{array}{c}-0.001 \\
(0.362)\end{array}$ & $\begin{array}{l}-0.001 \\
(0.415)\end{array}$ & $\begin{array}{c}0.000 \\
(0.770)\end{array}$ & $\begin{array}{c}0.000 \\
(0.831)\end{array}$ & $\begin{array}{c}0.000 \\
(0.715)\end{array}$ \\
\hline Leverage & $\begin{array}{c}0.000 \\
(0.340)\end{array}$ & $\begin{array}{c}0.000 \\
(0.342)\end{array}$ & $\begin{array}{c}0.000 \\
(0.390)\end{array}$ & $\begin{array}{c}0.000 \\
(0.244)\end{array}$ & $\begin{array}{c}0.000 \\
(0.226)\end{array}$ & $\begin{array}{c}0.000 \\
(0.276)\end{array}$ \\
\hline Cashholding & $\begin{array}{c}0.020 \\
(0.354)\end{array}$ & $\begin{array}{c}0.022 \\
(0.309)\end{array}$ & $\begin{array}{c}0.020 \\
(0.360)\end{array}$ & $\begin{array}{c}0.005 \\
(0.492)\end{array}$ & $\begin{array}{c}0.006 \\
(0.421)\end{array}$ & $\begin{array}{c}0.005 \\
(0.502)\end{array}$ \\
\hline CF/Equity & $\begin{array}{l}-0.001 \\
(0.911)\end{array}$ & $\begin{array}{l}-0.001 \\
(0.939)\end{array}$ & $\begin{array}{l}-0.002 \\
(0.893)\end{array}$ & $\begin{array}{c}0.008^{* *} \\
(0.045)\end{array}$ & $\begin{array}{c}0.008^{* *} \\
(0.040)\end{array}$ & $\begin{array}{c}0.007^{* *} \\
(0.047)\end{array}$ \\
\hline Runup & $\begin{array}{c}-0.011^{*} \\
(0.079)\end{array}$ & $\begin{array}{c}-0.012^{*} \\
(0.065)\end{array}$ & $\begin{array}{l}-0.010^{*} \\
(0.095)\end{array}$ & $\begin{array}{l}-0.001 \\
(0.464)\end{array}$ & $\begin{array}{c}-0.002 \\
(0.371)\end{array}$ & $\begin{array}{l}-0.001 \\
(0.526)\end{array}$ \\
\hline Sigma & 0.253 & 0.244 & 0.260 & $-0.245^{* *}$ & $-0.250^{* *}$ & $-0.244^{* *}$ \\
\hline
\end{tabular}


Table 12 - continued from previous page

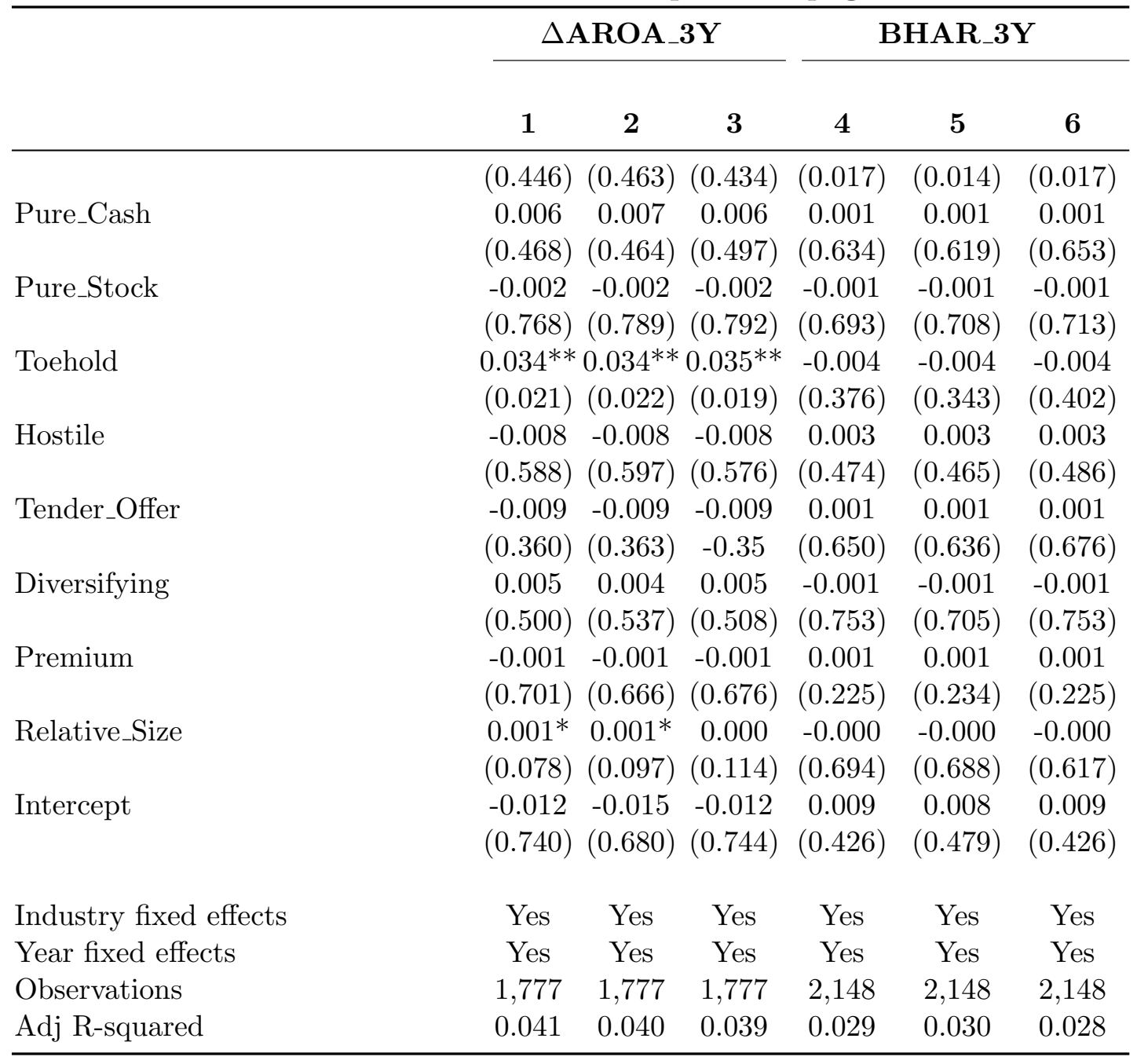


Table 13: Institutional cross-ownership and information asymmetry: Sub-sample analyses

This table presents the OLS regression results of the deal performance on the institutional cross-ownership proxy variables. The sample consists of our initial 2,604 M\&A public deals with non-missing values of all the variables in the regressions. We divide our main sample into two sub-samples based on the medians of Analyst, the number of financial analysts following. The low sub-sample includes deals in which targets have below-median analyst coverage in the fiscal year before the deal announcement, and the high sub-sample includes deals in which targets have above-median analyst coverage in the fiscal year before the deal announcement. The dependent variables are short-term and long-term deal performance measures: Synergy, $\triangle$ AROA_3Y, and BHAR_3Y. In Panel A-C, the primary explanatory variables of interest are Top10Count, Top10CountIndependent, and Top10CountDedicated/Quasi-index, respectively. The coefficients of all the control variables as in Table 11 and Table 12, year fixed effects, and Fama-French 10 industry fixed effects are suppressed for brevity in the respective columns. Detailed definitions of the control variables are given in Appendix A. Regression standard errors are adjusted for heteroscedasticity (White, 1980). p-values are reported in parentheses. $* * *$, ** and $*$ denote statistical significance at the $1 \%, 5 \%$ and $10 \%$ levels, respectively.

\begin{tabular}{|c|c|c|c|c|c|c|}
\hline \multirow[b]{2}{*}{ Variables } & \multicolumn{2}{|c|}{ Synergy } & \multicolumn{2}{|c|}{$\triangle$ AROA_3Y } & \multicolumn{2}{|c|}{ BHAR_3Y } \\
\hline & $\begin{array}{l}(1) \\
\text { Low }\end{array}$ & $\begin{array}{c}(2) \\
\text { High }\end{array}$ & $\begin{array}{l}(3) \\
\text { Low }\end{array}$ & $\begin{array}{c}(4) \\
\text { High }\end{array}$ & $\begin{array}{l}(5) \\
\text { Low }\end{array}$ & $\begin{array}{c}(6) \\
\text { High }\end{array}$ \\
\hline $\begin{array}{l}\text { Panel A. Top10Count } \\
\text { Top10Count }\end{array}$ & $\begin{array}{r}0.061^{* *} \\
(0.019)\end{array}$ & $\begin{array}{l}-0.004 \\
(0.554)\end{array}$ & $\begin{array}{l}0.012^{* *} \\
(0.012)\end{array}$ & $\begin{array}{c}0.000 \\
(0.902)\end{array}$ & $\begin{array}{l}0.002^{*} \\
(0.062)\end{array}$ & $\begin{array}{c}0.002 \\
(0.208)\end{array}$ \\
\hline Firm characteristics & Yes & Yes & Yes & Yes & Yes & Yes \\
\hline Deal characteristics & Yes & Yes & Yes & Yes & Yes & Yes \\
\hline Industry \& year fixed effects & Yes & Yes & Yes & Yes & Yes & Yes \\
\hline Observations & 1,050 & 948 & 727 & 707 & 893 & 813 \\
\hline Adj R-squared & 0.068 & 0.058 & 0.102 & 0.056 & 0.064 & 0.080 \\
\hline
\end{tabular}

Panel B. Top10CountIndependent

Top10CountIndependent

$\begin{array}{llllll}0.078^{* *} & -0.004 & 0.016^{* *} & 0.001 & 0.004^{* *} & 0.002\end{array}$

$\begin{array}{llllll}(0.026) & (0.698) & (0.014) & (0.767) & (0.022) & (0.187)\end{array}$

Firm characteristics

Deal characteristics

Yes Yes Yes Yes Yes Yes

Industry \& year fixed effects

Yes Yes Yes Yes Yes Yes

Observations

Yes Yes Yes Yes Yes Yes

Adj R-squared

$\begin{array}{llllll}1050 & 948 & 727 & 707 & 893 & 813\end{array}$

$\begin{array}{llllll}0.067 & 0.057 & 0.102 & 0.056 & 0.066 & 0.080\end{array}$

Panel C. Top10CountDedicated/Quasi-index

Top10CountDedicated/Quasi-index $0.064^{* *} \quad 0.003 \quad 0.009^{*} \quad-0.000 \quad 0.001^{*} \quad 0.002$

$\begin{array}{llllll}(0.018) & (0.725) & (0.063) & (0.935) & (0.074) & (0.145)\end{array}$ 
Table 13 - continued from previous page

\begin{tabular}{|c|c|c|c|c|c|c|}
\hline \multirow[b]{3}{*}{ Variables } & \multicolumn{2}{|c|}{ Synergy } & \multicolumn{2}{|c|}{$\triangle \mathrm{AROA}_{-3 \mathrm{Y}}$} & \multicolumn{2}{|c|}{ BHAR_3Y } \\
\hline & $(1)$ & $(2)$ & $(3)$ & $(4)$ & $(5)$ & $(6)$ \\
\hline & Low & High & Low & High & Low & High \\
\hline Firm characteristics & Yes & Yes & Yes & Yes & Yes & Yes \\
\hline Deal characteristics & Yes & Yes & Yes & Yes & Yes & Yes \\
\hline Industry \& year fixed effects & Yes & Yes & Yes & Yes & Yes & Yes \\
\hline Observations & 1,050 & 948 & 727 & 707 & 893 & 813 \\
\hline Adj R-squared & 0.068 & 0.057 & 0.098 & 0.056 & 0.061 & 0.080 \\
\hline
\end{tabular}


Figure 1: Distribution of institutional owners and cross-owners. This bar chart of the figure presents the annual distribution of average numbers of institutional owners of acquirers and targets and the institutional cross-owners. The institutional cross-owners are defined as the institutional investors who hold both acquirer and target stocks before the M\&A announcements. The line chart of the figure also presents the distribution of the average ratio of cross-owners for acquirers and targets for each announcement year. The value on the left axis denominates the number of institutional owners and the right axis denominates the percentage of the cross-owners in total institutional investors. Our sample includes 2,604 M\&A deals between 1984 and 2014. Both the acquirer and the target are U.S. public firms with complete information in the CRSP and Compustat databases and they have institutional ownership information from the Thomson Financial CDA/Spectrum Institutional (13F) database. Detailed definitions of all variables can be found in Appendix A.

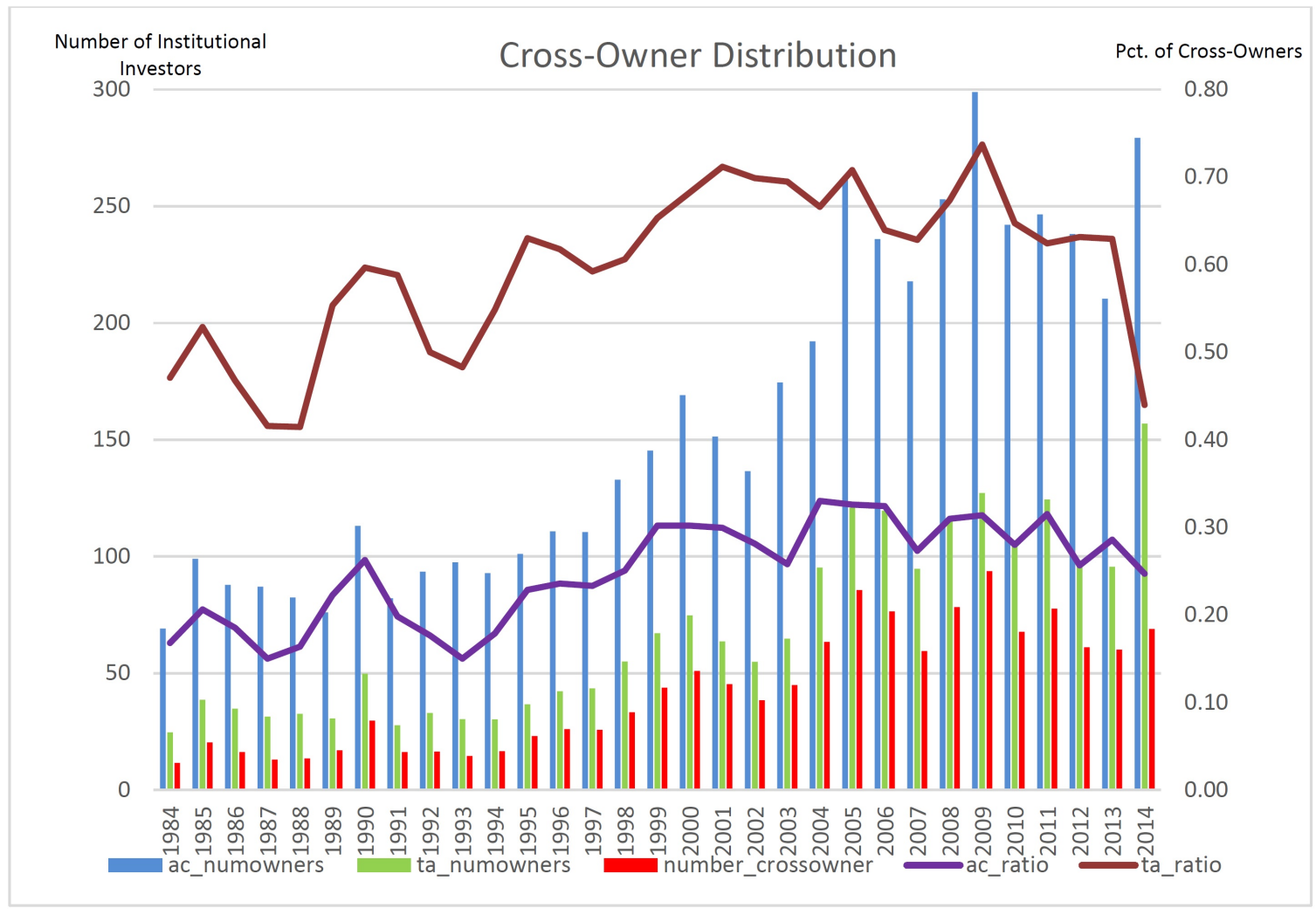

